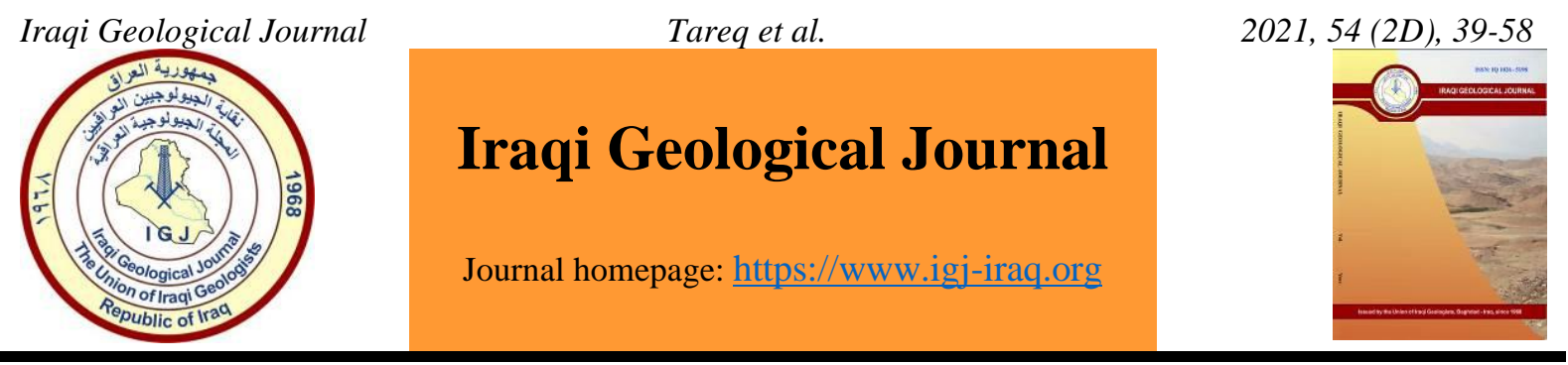

\title{
Lithological Study of Mishrif, Rumaila, Ahmadi and Mauddud Formations Using Vp/ Vs Ratio, Acoustic Impedance and Well Logging at Amara Oil Field, Southern Iraq
}

\author{
Hiba Tareq ${ }^{1, *}$, Ahmed Al-Banna ${ }^{1}$ and Ghazi Al-Sharaa ${ }^{2}$ \\ 1 Department of Geology, Collage of Science, University of Baghdad, Baghdad, Iraq \\ 2 Oil Exploration Company, Iraq \\ * Correspondence: yousif8181@yahoo.com
}

Received: 1 May 2021; Accepted: 27 July 2021; Published: 31 October 2021

\begin{abstract}
The lithology of four formations from the Cretaceous period (Mishrif, Rumaila, Ahmadi, and Mauddud) was evaluated using the Acoustic Impedance and Vp/Vs ratio cross plot from Rock Physics Templates. Dipole sonic logs in Am-6-Am-10 well log were used to calculate compression velocity then the estimated shear velocity using Greenberg Castagna equations. RHOB and VP logs were used to calculate Acoustic Impedance. The ratio of $\mathrm{Vp} / \mathrm{Vs}$ was measured then used with Acoustic Impedance colored by shale volume which is measured from gamma ray log, porosity and water saturation to estimate lithology type of the considered formations using cross plots and rock physics chart in the Techlog software. The lithology of the formations found to be of high porosity limestone alternating with hard limestone layers and the shale volume increases in the Ahmadi formation. The water bearing zone was found in all Formations, this zone is indicted by high $\mathrm{Vp} / \mathrm{Vs}$ ratio and low AI. The hydrocarbon bearing zones were indicated by low amount of both Acoustic Impedance and $\mathrm{Vp} / \mathrm{Vs}$ ratio and this observation was shown in Mishrif and Mauddud formations.
\end{abstract}

Keywords: Middle Cretaceous; Vp/Vs Ratio; Acoustic impedance; Amara Oil Field; Southern Iraq

\section{Introduction}

The Amara oil field is located within the unstable shelf within the zone of the Mesopotamian basin near the northeastern slope of the Arab-African platform (Fouad, 2010, Al-Banna and Ali, 2018). This field is considered as one of the small fields located in the region, such as Al-Rafidain, Ali-Al-Sharqi, Kumait, Dujailla and Al-Rifai (Khanawi et al., 2010). This field represents an anticline structure, which was discovered for the first time by seismic exploration survey at 1958. The seismic reinterpretation indicated that the anticline axis of Amara oil field trends from NW-SE (M.O.C, 2011). The length of top Mishrif structure in Amara oil field is $18 \mathrm{~km}$ and its width is $4.5 \mathrm{~km}$ with enclosure of about $80 \mathrm{~m}$ (FGR Am-6 well). The combination of compression velocity Vp, shear velocity Vs and bulk density are used to determine elastic constants (Colin et al., 1997), while the $\mathrm{Vp} / \mathrm{Vs}$ ratio gives additional information about lithology (Nassir et al., 2020). The Shear velocity (Vs) is one of important physical properties, which is calculated normally from shear sonic log "shear interval transit time ", but the Vs have not been recorded for the old wells due to the lack of logging equipment or limited funds (Wang,

DOI: $\underline{10.46717 / i g j .54 .2 D .4 M s-2021-10-23}$ 
2019). There are many studies discussed the determination of Vs from VP depending on rock physics and statistical empirical regressions equations. In this study the equations of Greenberg and Castagna, (1992) will be used to calculate Vs from Vp at Am-6 and Am-10 wells from Amara oil field for four carbonate formations from middle Cretaceous period. These formations are Mishrif, Rumiala, Ahmadi and Mauddud; these formations are different in lithology, the percentage of minerals and petrophysical properties that effect density and velocity logs deflection. Acoustic impedance is a physical property of the rocks and it depends on lithology type, porosity percentage, fluid saturation and other factors (Latimer et al., 2000; Awadh et al., 2018; Al-Mimar et al., 2018). Many studies were done using well log data in multiple results, (Al-Baldawi, 2020) determined the pore type and porosity trend by convert sonic and neutron porosity or density porosity to velocity deviation log using means of time average equations in Mishrif Formation taking data from two wells in Halfaya oil field. (Mohammed et al., 2020) produced and compared the missing neutron, density and deep resistivity logs together using the Artificial Neural Network ANN in Petrel software. of the Early Cretaceous Nahr Umr Sandstone and the Late Cretaceous Mishrif formations of the well Noor- 10.

\section{Locations of the Study Area}

Amara oil field lies on Messan at distance 20km east of Al Rafidden structure and 20km south east Kumait structure (Fig.1) (IPEC, 2010). Table 1 shows the coordinates of studied wells.

Table 1. The coordinates of Am-6 and Am-10 wells

\begin{tabular}{ccccc}
\hline & E & N & RTKB Elevation(m) & Ground Elevation(m) \\
\hline Well & & & 14.4 & 5.8 \\
Am-6 & 699045 & 3518582 & 14.4 & 5.6 \\
\hline
\end{tabular}

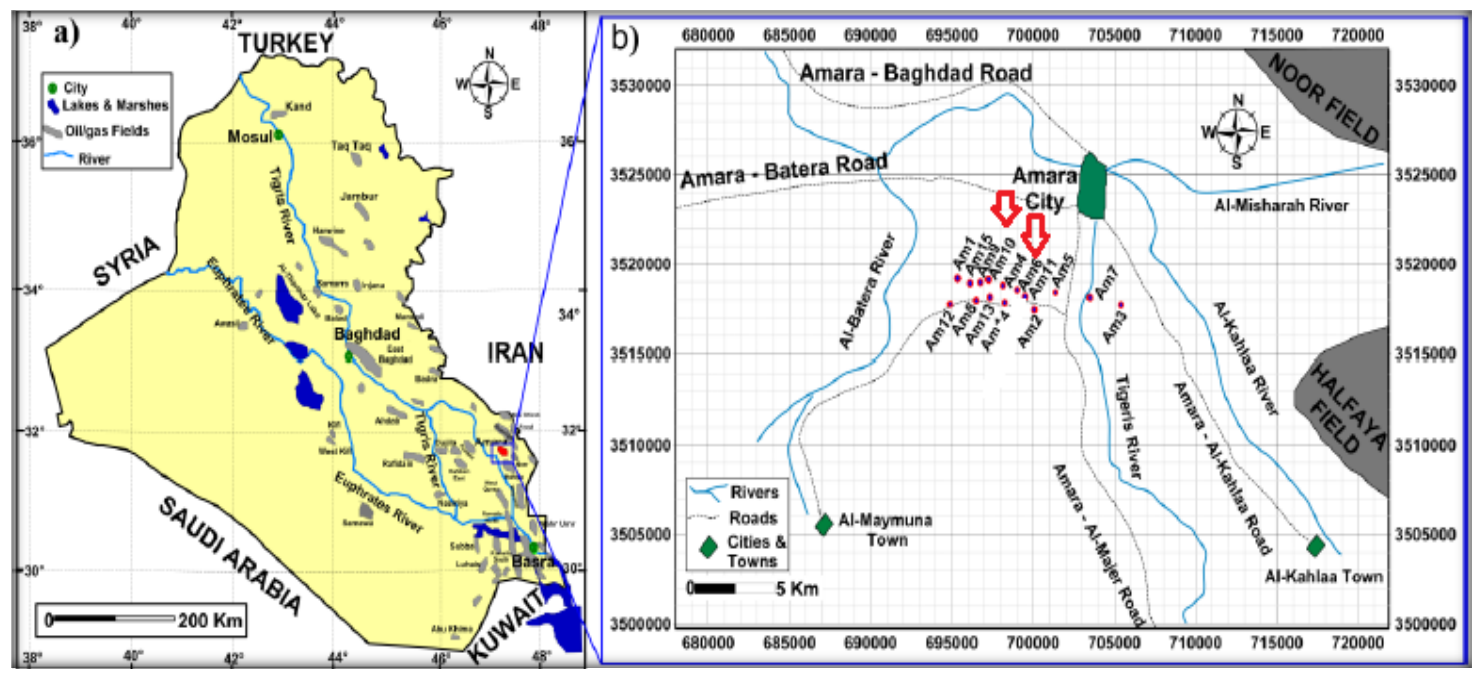

Fig.1. The Amara oil field map (Sadooni, 2004), the wells location (adapted from M.O.C. Maps)

\section{The Geology of Amara Oil Field}

The surface of the study area is covered with sediments of the Quaternary period (Pleistocene and Modern Era), which consist of fine sand, clay and gravel (IPEC, 2010). The stratigraphic section in the 
field was identified and the formation depths were determined see Table 2 and Fig.2, while a comparison between the thicknesses of the geological formations was made.

Table 2. The top of the formations at studied wells (Am-6, and Am-10)

\begin{tabular}{lcc}
\hline Formation & $\begin{array}{c}\text { Top }(\mathbf{m}) \\
\text { well, Am6 }\end{array}$ & $\begin{array}{c}\text { Top(m) } \\
\text { well, Am10 }\end{array}$ \\
\hline Mishrif & 2864.5 & 2874 \\
Rumiala & 3270 & 3272 \\
Ahmadi & 3285 & 3284 \\
Mauddud & 3311 & 3309 \\
\hline
\end{tabular}

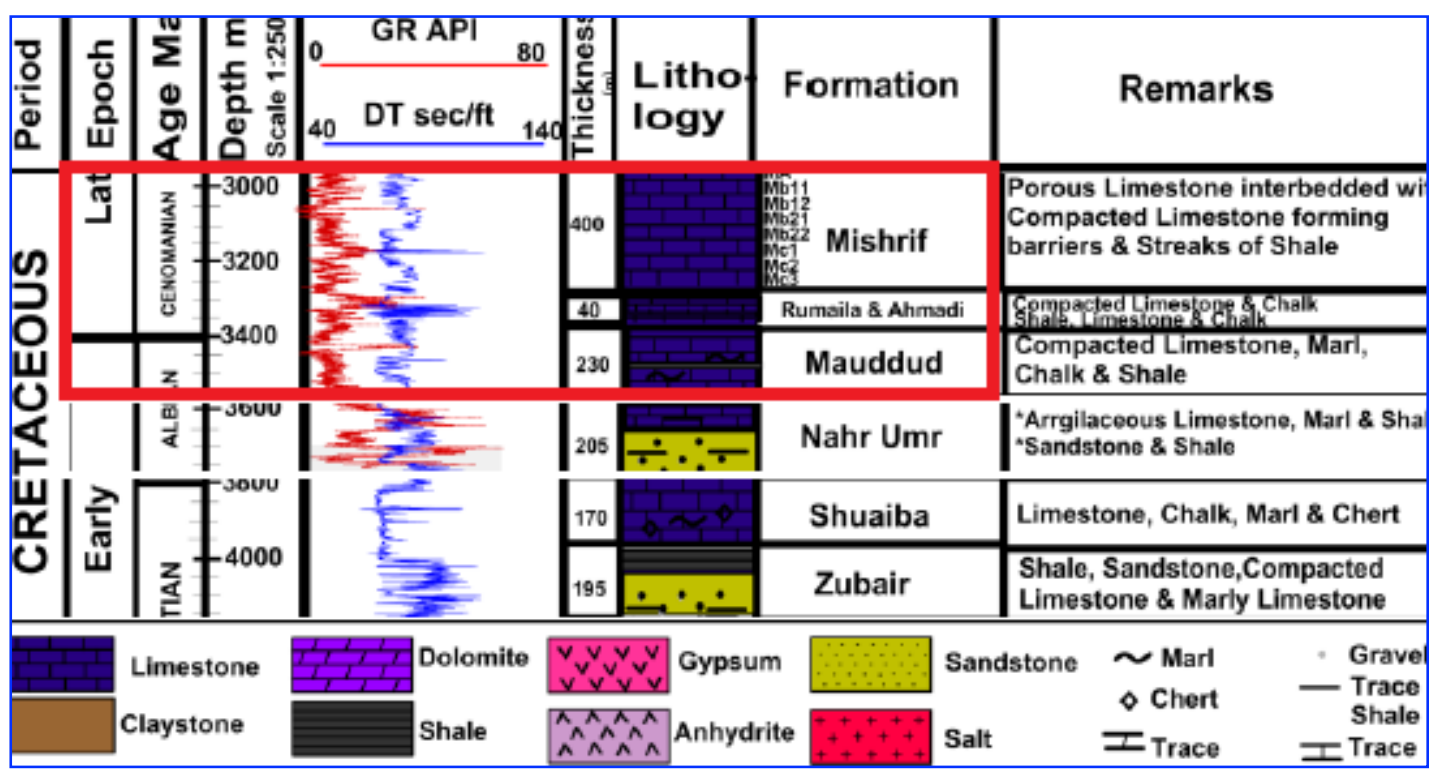

Fig. 2. The composite stratigraphic column of the southern region, Iraq (Mohammed, 2018)

According to the previous studies and final geological reports (M.O.C., 2015) for the two wells Am-6 and Am-10, the studied formation consists of the following:

\subsection{Mishrif Formation}

Which is composed mainly of many types of limestone (porous, compact and chalky limestones) with shale layers. The Mishrif Formation from middle Cretaceous late Cenomanian, the thickness of the Mishrif Formation in Amara oil field almost more than $\approx 400 \mathrm{~m}$ in total and it forms eight sub units with barriers between them. (Al-Baldawi, 2015)

\subsection{Rumaila Formation}

From M. Cretaceous to M. Cenomanian, with low thickness $\approx 14 \mathrm{~m}$ in total, it is composed of compact limestone only.

\subsection{Ahmadi Formation}

From M. Cretaceous to M. Cenomanian, with low thickness $\approx 26 \mathrm{~m}$ in total, it is composed of compact limestone and high shale volume. (Aqrawi et al., 2010). 


\subsection{Mauddud Formation}

From Cretaceous to E. Cenomanian age and it is composed of porous limestone, chalky limestone and compact limestone with shale, formation thickness $\approx 225 \mathrm{~m}$ in total. (IPEC, 2010).

\section{Materials and Methods}

The work procedures which are used to achieve the results pass throw many steps: at the beginning the available log data were loaded and processed by applying environmental correction for hole size, pressure and temperature to the bulk density, neutron porosity, gamma ray and resistivity data, then the shale volume where calculated from corrected gamma ray log which is used as lithology identification tool, NPHI was read directly from the field and represented the neutron porosity that depends on the fluid amount in the pores and the percentage of hydrogen concentration, RHOB is a bulk density $\log$ that reflects the density of matrix and saturated fluid density while the Neutron-Density porosity (effective and total ) were determined using neutron and bulk density logs, water saturation was calculated using Archie's equation after having the water resistivity from salinity method and a, $\mathrm{n}$ and $\mathrm{m}$ parameters from Pickett plot (Asquith, 2004).These logs data were used to evaluate the lithology type with depth connected with crossplot of AI \&Vp/Vs. lithology type according to the differentiation between logs curves are used to evaluate the lithology of formations using Density and NPHI logs to draw crossplot between RHOB-NPHI. The Vp was calculated from Dt (interval transit time log) and then Green Castagna, 1992 equation was used to calculate Vs from Vp, this method uses many equations (1,2 and 3$)$ for each lithology type and depends on Vp data.

For limestone

For sandstones

For shale

$$
\begin{aligned}
\mathrm{Vs}=-0,05508 \mathrm{Vp} 2+1.01677 \mathrm{Vp}-1.03049 \\
\mathrm{Vs}=0.8042 \mathrm{Vp}-855.88 \\
\mathrm{Vs}=0.76969 \mathrm{Vp}-867.35
\end{aligned}
$$

The fluid mixing rock model was used to evaluate fluid density distributed with depth for each formation using the petrophysical parameters as input especially water saturation log, the estimated fluid density $\log$ was used to evaluate our final result. According to the relation between bulk density and velocity with rock physics that depends on lithology type, fluid type, porosity percentage and fluid saturation the formation can be evaluated and hydrocarbon depths can be determined (Hami-Eddine et al., 2015). Acoustic impedance and the ratio between $\mathrm{Vp} / \mathrm{Vs}$ were used to determine lithology and fluid types, where the decrease in $\mathrm{AI}$ value and the $\mathrm{Vp} / \mathrm{Vs}$ ratio indicate the presence of hydrocarbon fluid, while the increase in AI with the decrease in the VP/VS ratio reflects the increase in cement value, and the decrease of AI with increase in Vp/Vs indicates porosity with water saturation (Avseth et al., 2006). The Vp/Vs, AI crossplots were drawn and colored with shale volume, effective porosity, total porosity and water saturation to evaluate formations lithology type and fluid type with depth.

\section{Results and discussion}

The lithology of four formations is evaluated using schlumberger, 2005-2010-RHOB, NPHI cross plot. Figs 3, 4, 5 and 6 reflect the result from RHOB, NPHI crossplot for each formation in the two wells. Mishrif, Rumiala, Ahmadi and Mauddud formations points were distributed around limestone line represent the main lithology is limestone with some points cluster near dolomite line represent the exist of dolomite in thin depths of Mishrif of Am10 well, Ahmadi and Mauddud either. The points that clustered near sandstone line may occur either as results of exist some deposits from chemical Chert minerals or as result to increase shale volume in this point. The formations known as not homogeneous and it contain many things affect the crossplot result. 

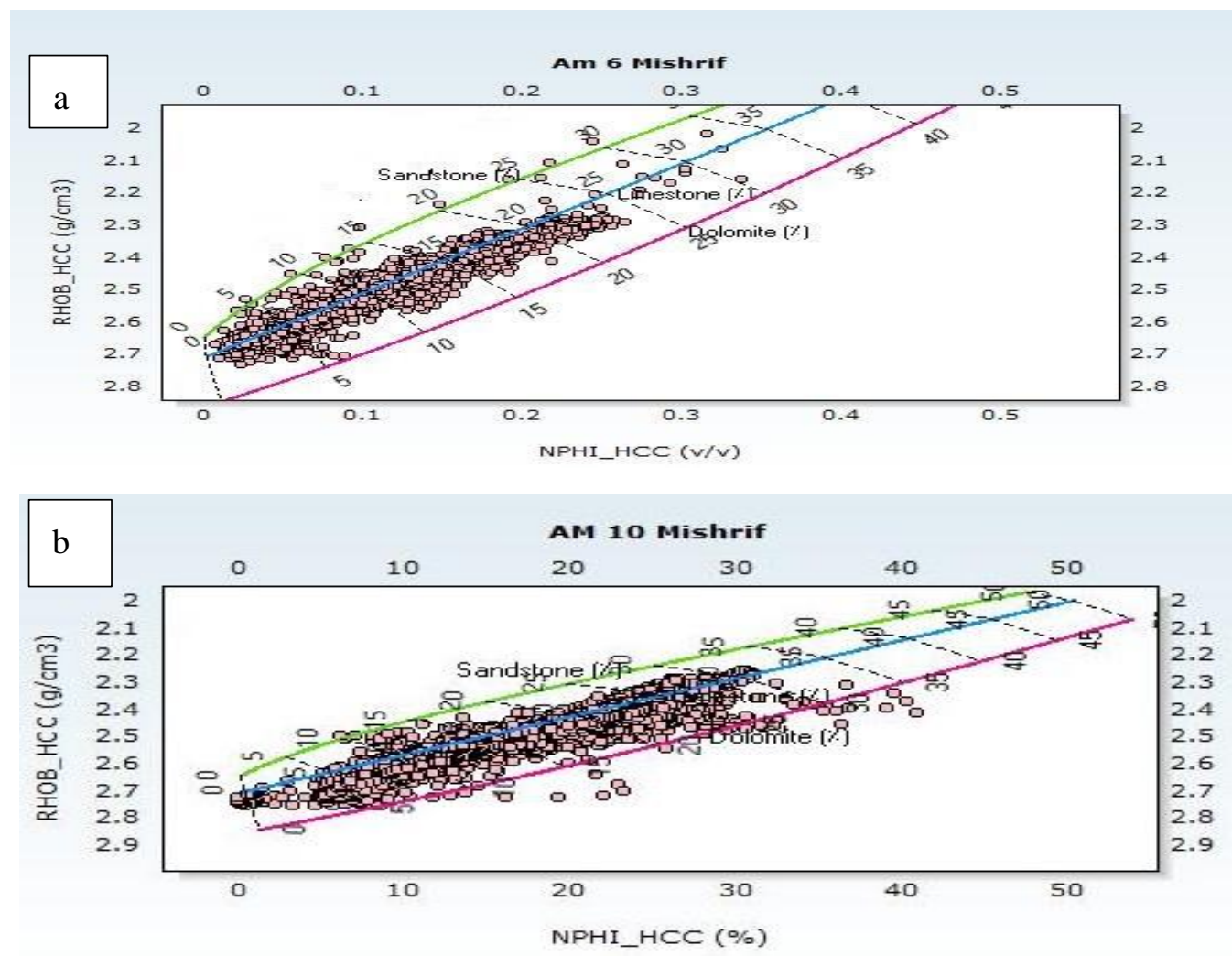

Fig. 3. Mishrif, Formation lithology crossplot from using NPHI with RHOB logs a) In Am-6, b) Am10 wells of Amara oil field
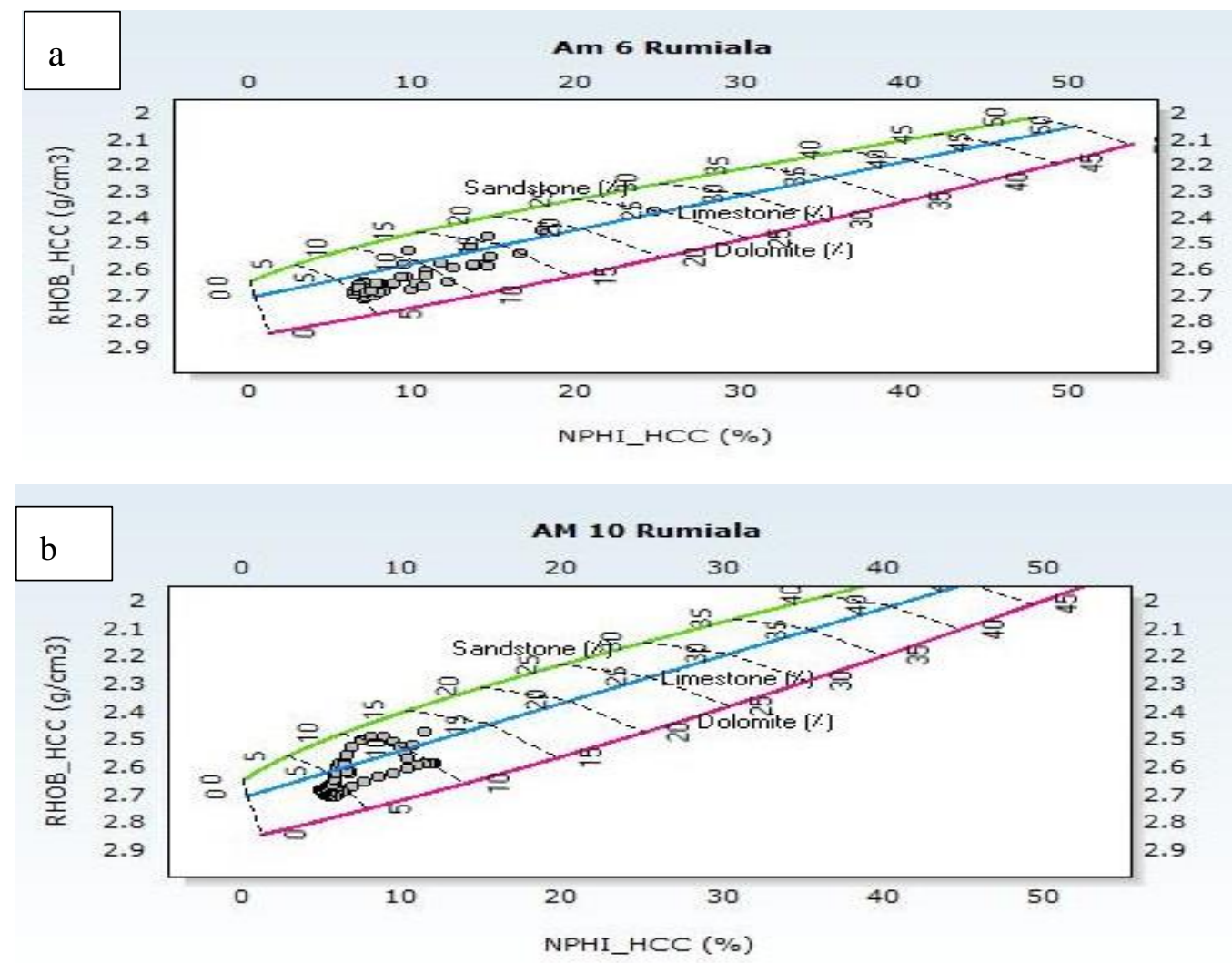

Fig.4. Rumaila Formation lithology crossplot from using NPHI with RHOB logs a) In Am-6, b) Am10 wells of Amara oil field 

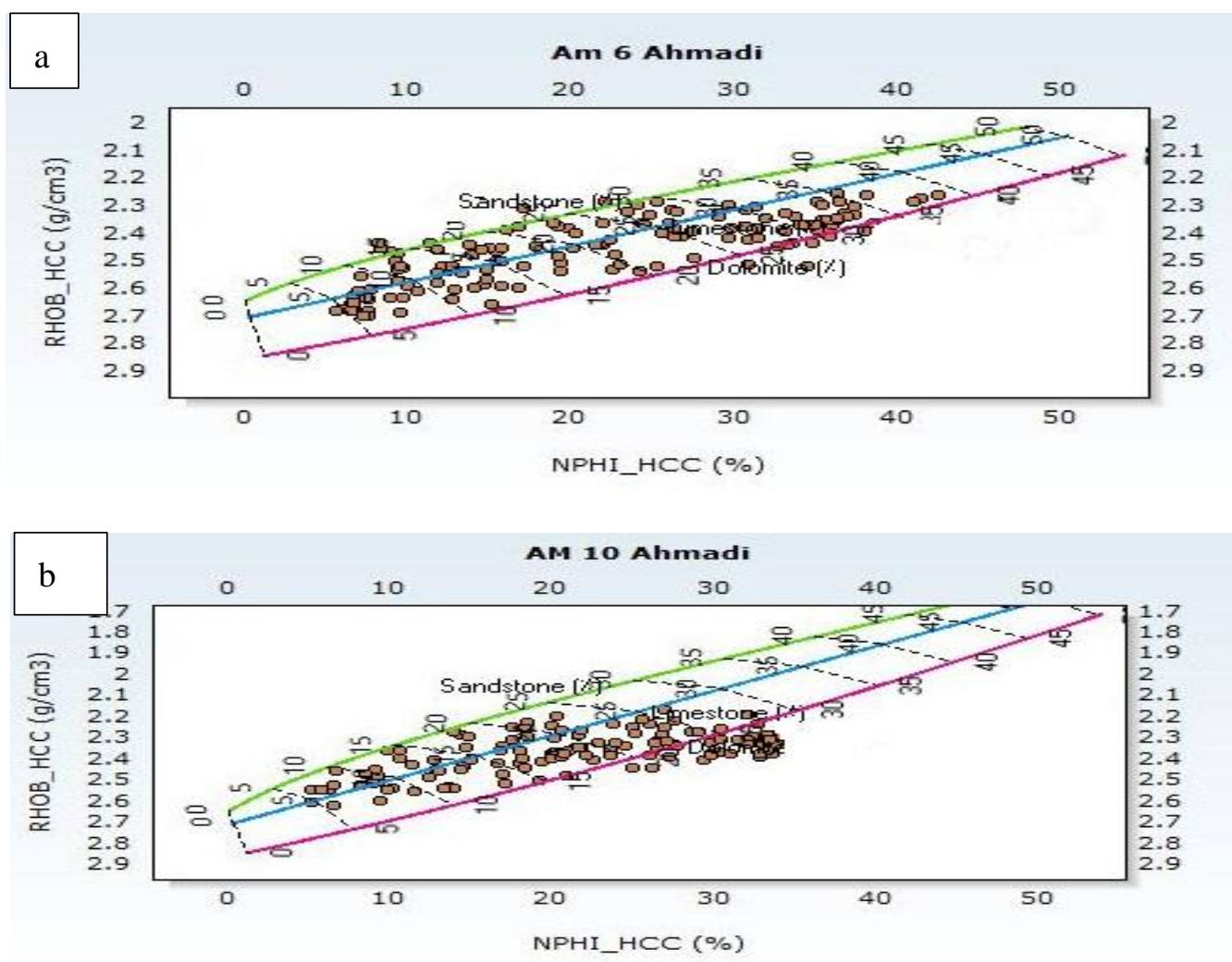

Fig. 5. Ahmadi Formation lithology crossplot from using NPHI with RHOB logs, a) In Am-6, b) Am10 wells of Amara oil field
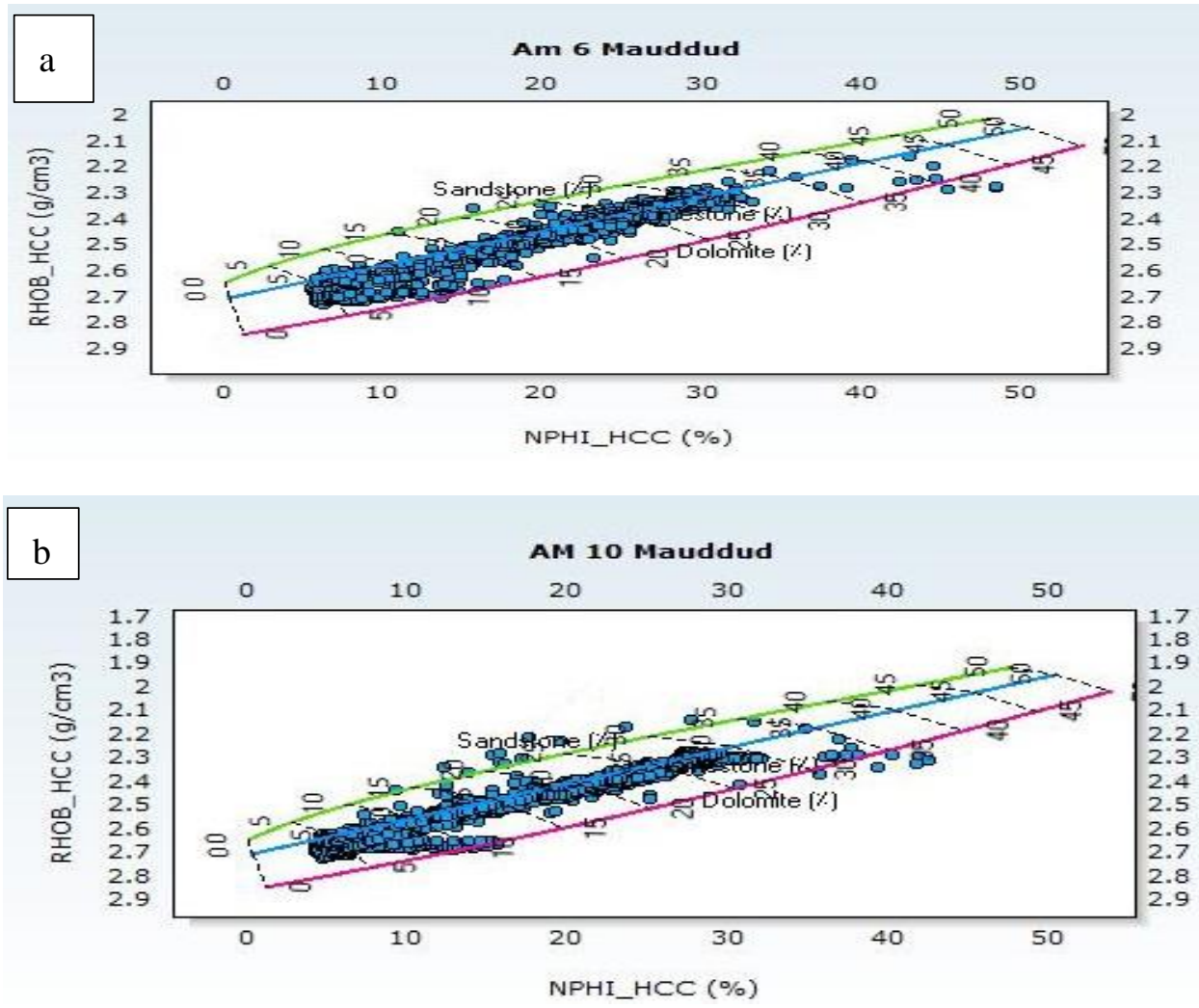

Fig. 6. Mauddud Formation lithology crossplot from using NPHI with RHOB logs a) In Am-6, b) Am-10 
Figs 7, 8, 9 and10 show the relationship between Acoustic impedance on the $\mathrm{x}$ axes and $\mathrm{Vp} / \mathrm{Vs}$ ratio on the $\mathrm{Y}$ axes. Each figure has five plots for each well, the first plot shows the distribution points colored by shale volume, the second plot colored by ND total porosity, third plot colored by ND effective porosity, and forth plot colored by water saturation and the final plot represents the formation points colored according to the interpretation of the formations. The percentages of AI, Vsh, EPHI, TPHI, Sw and $\mathrm{Vp} / \mathrm{Vs}$ for the whole formations were discussed below. Figs.7, 8, 9, 10 and 11) show three clusters of colored points, the blue points represent depths with low shale volume, low TPHI, EPHI and high Sw. The AI ranges 13500 to 16811 . g.m/cm3.s and Vp/Vs 1.79 to 1.93 . The lithology of this formation is limestone with high water saturation as fluid type.

The green points represent depths with increasing TPHI and EPHI and decreasing the Sw and that lead to AI ranges from 9000 to $13000 \mathrm{~g} . \mathrm{m} / \mathrm{cm} 3 . \mathrm{s}$ and This part reflect porous limestone with water as fluid. The light green points have range of AI from 6800 to aprroximatly $11000 \mathrm{~g} . \mathrm{m} / \mathrm{cm} 3 . \mathrm{s}$ and $\mathrm{Vp} / \mathrm{Vs}$ from 1.71 to 2 it represents high porosity and low water saturation depths with low density, the oil exist at point with low $\mathrm{AI}$ and $\mathrm{Vp} / \mathrm{Vs}$ and it depends on the oil and water volume percentage. The Mishrif Formation at well-10 is the same, with two colored areas the blue and green points. Fig.12, 13, 14, 15 and 16) show two colored points clustered in Am-6, the blue points distributed along limestone line with low value of Vsh and TPHI, EPHI and high Sw, AI range from 13000 to $15600 \mathrm{~g} . \mathrm{m} / \mathrm{cm} 3 . \mathrm{s}$ with $\mathrm{Vp} / \mathrm{Vs}$ range between 1.79- 1.8, while the green point area represents depths with low SW and high porosity little than Am-10 so the lithology is limestone with low porosity and high water saturation as fluid type. For Am-10 AI range between 13000-15438 g.m/cm3.s and Vp/Vs range between 1.8-1.9 and it indicates low porosity limestone with water fluid.
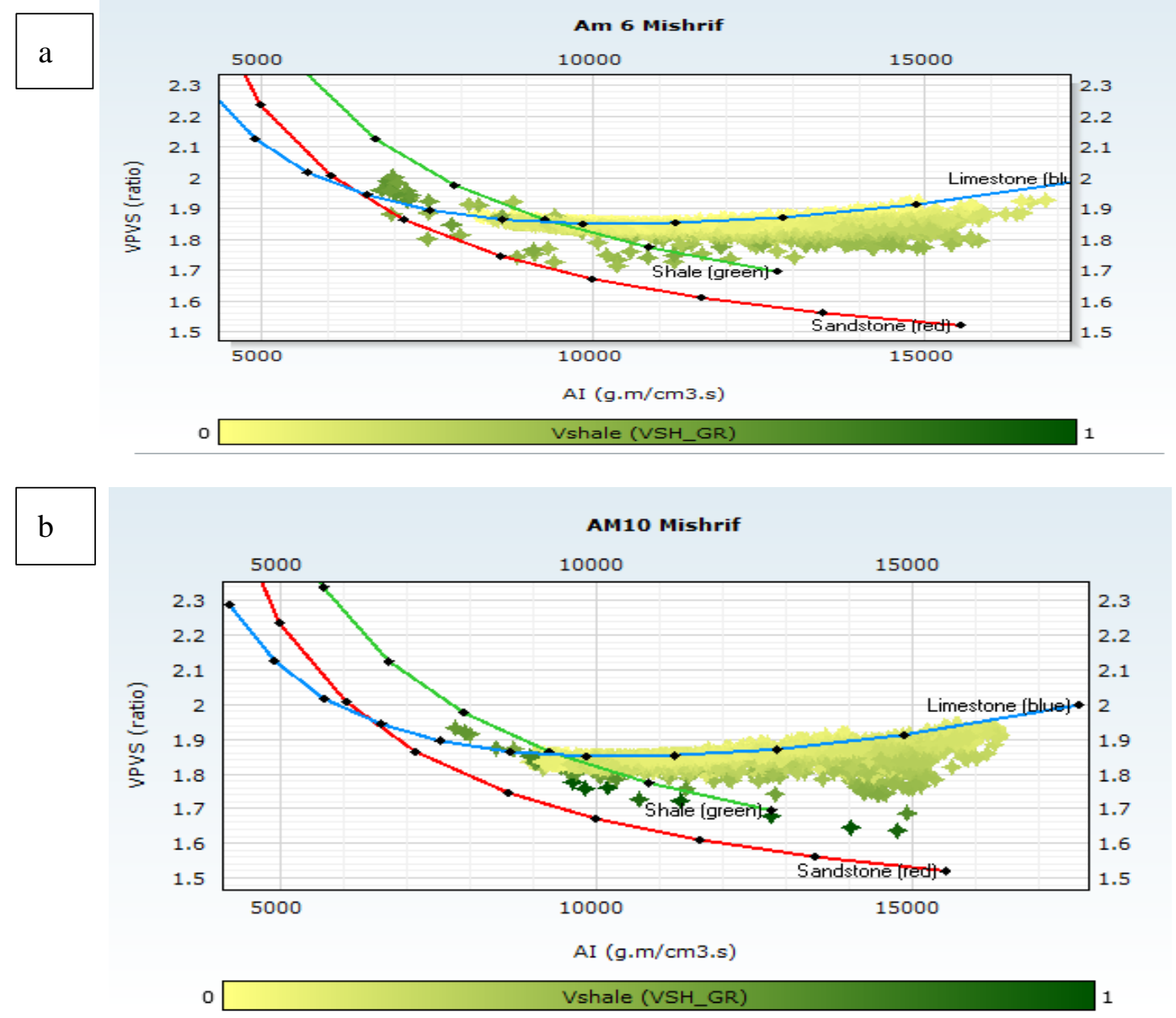

Fig. 7. The acoustic impedance versus the $\mathrm{Vp} / \mathrm{Vs}$ ratio colored by shale volume for the Mishrif Formation in Amara oil field a) at Am-6 b) at Am-10 

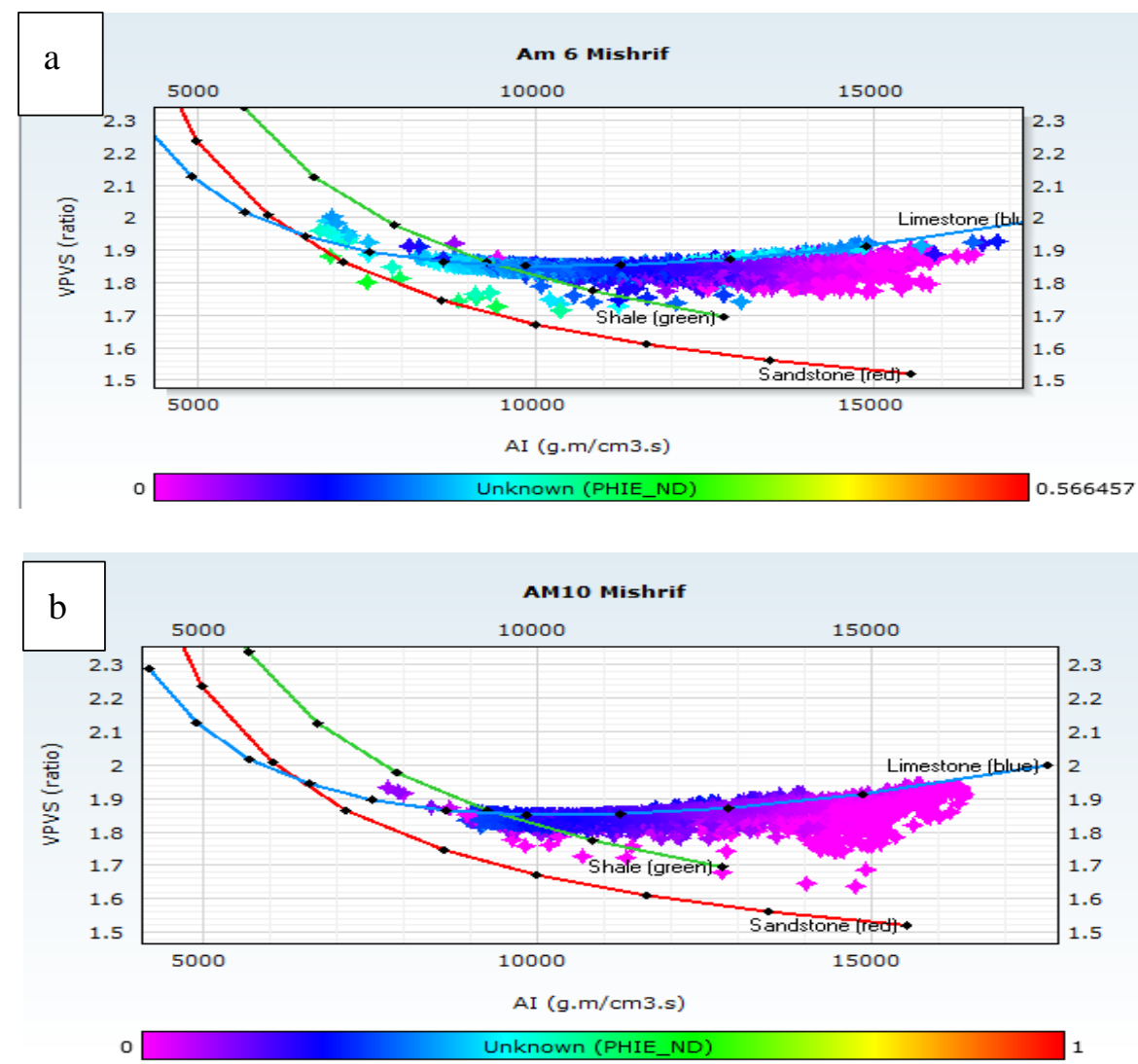

Fig. 8. The acoustic impedance versus the $\mathrm{Vp} / \mathrm{Vs}$ ratio colored by effective porosity for the Mishrif Formation in Amara oil field a) at Am-6 b) at Am-10
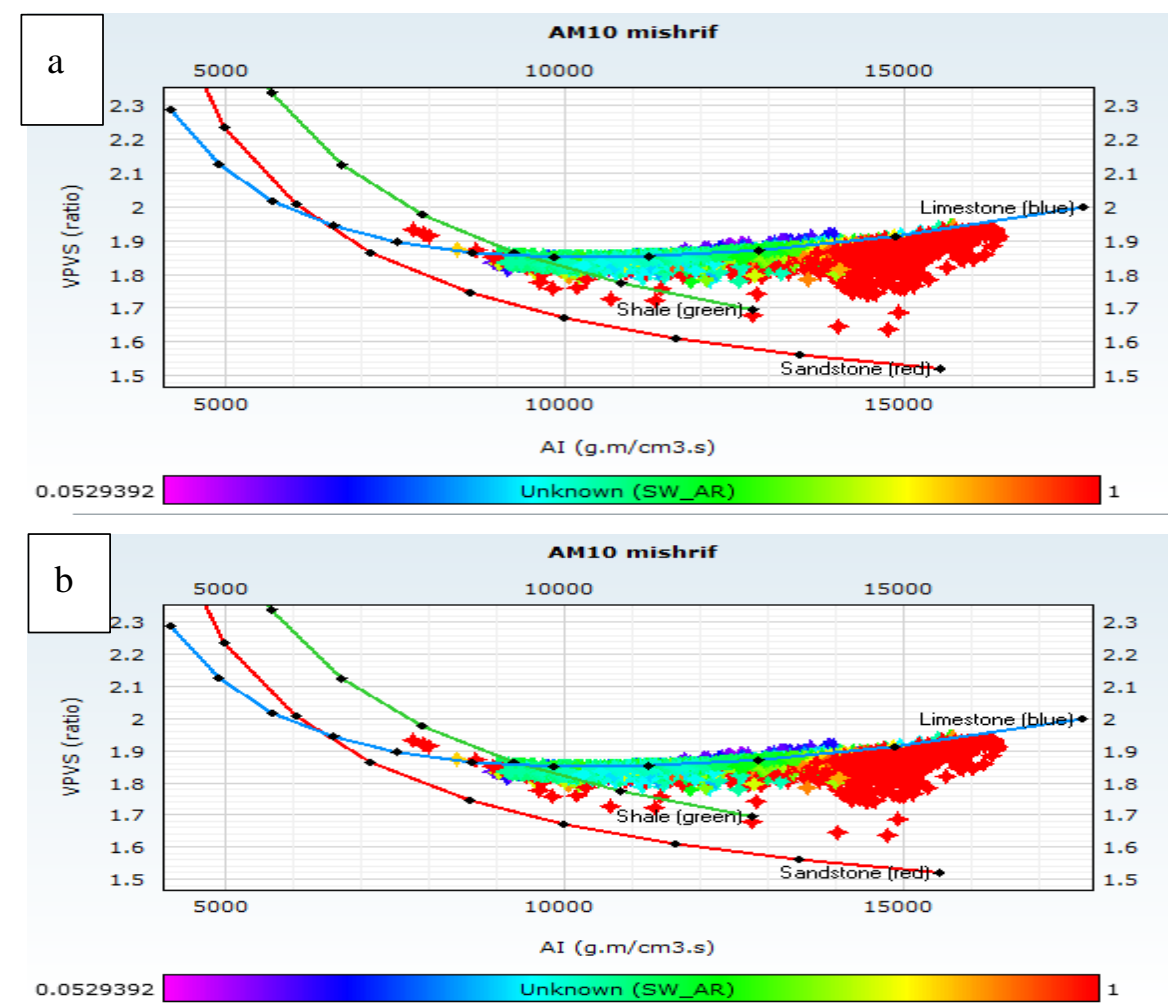

Fig. 9. The acoustic impedance versus the $\mathrm{Vp} / \mathrm{Vs}$ ratio colored by water saturation for the Mishrif Formation in Amara oil field a) at Am-6 b) at Am-10 

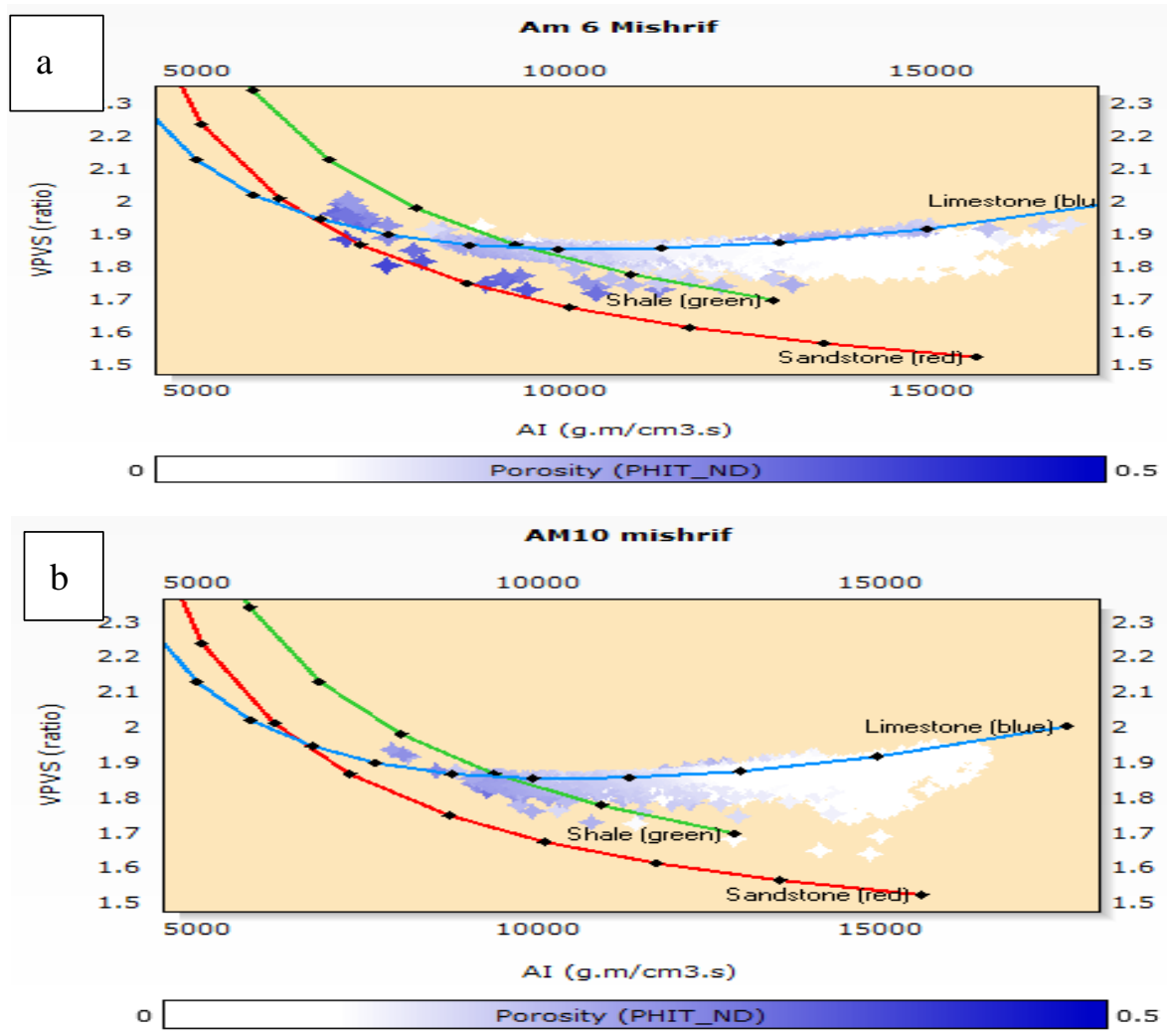

Fig. 10. The acoustic impedance versus the Vp/Vs ratio colored by total porosity for the Mishrif Formation in Amara oil field a) at Am-6 b) at Am-10
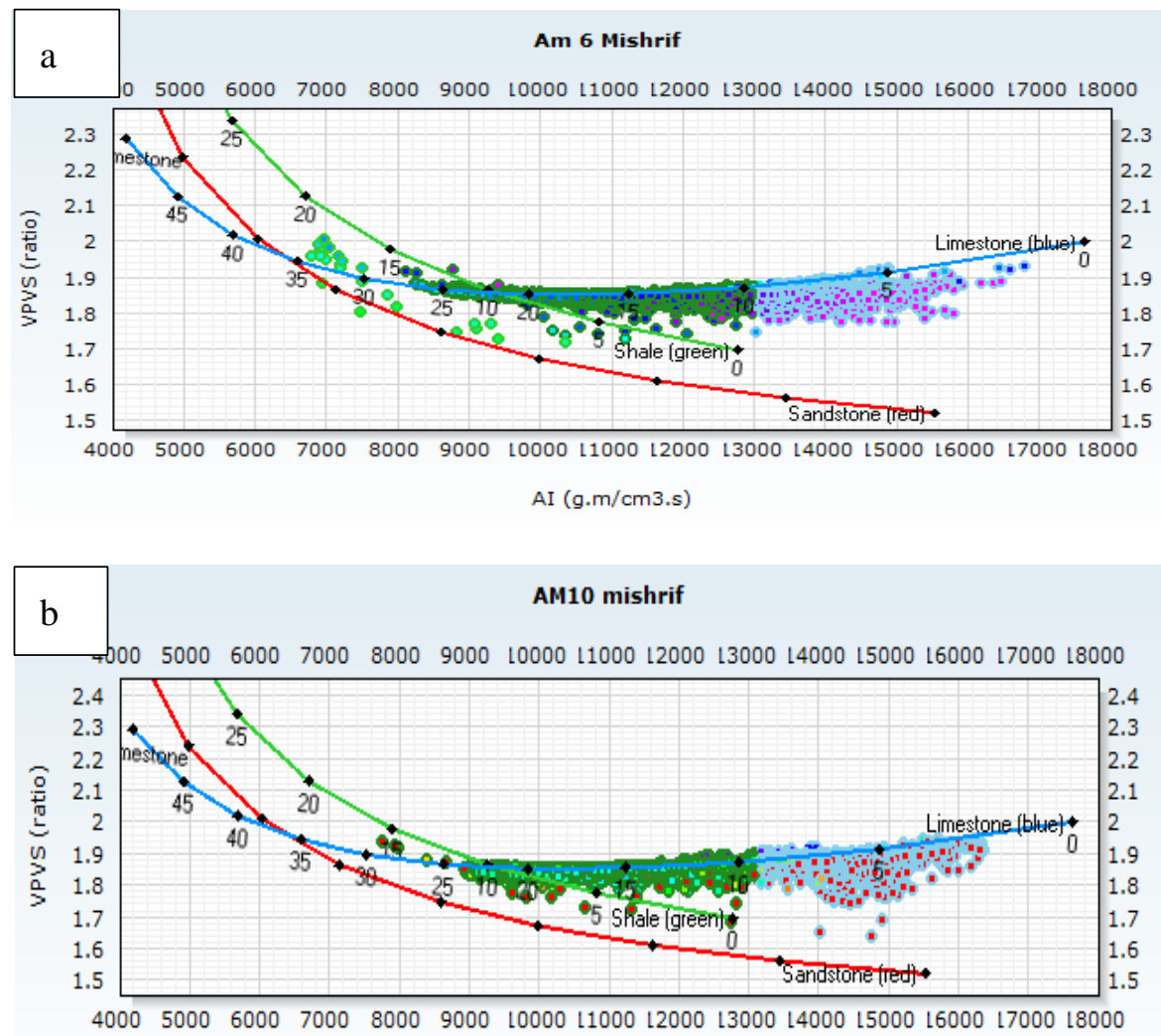

$$
\text { AI (g.m/cm3.s) }
$$

Fig. 11. Interpretation colored according to the value of the acoustic impedance versus the $\mathrm{Vp} / \mathrm{Vs}$ ratio for the Mishrif Formation in Amara oil field a) at Am-6 b) at Am-10 

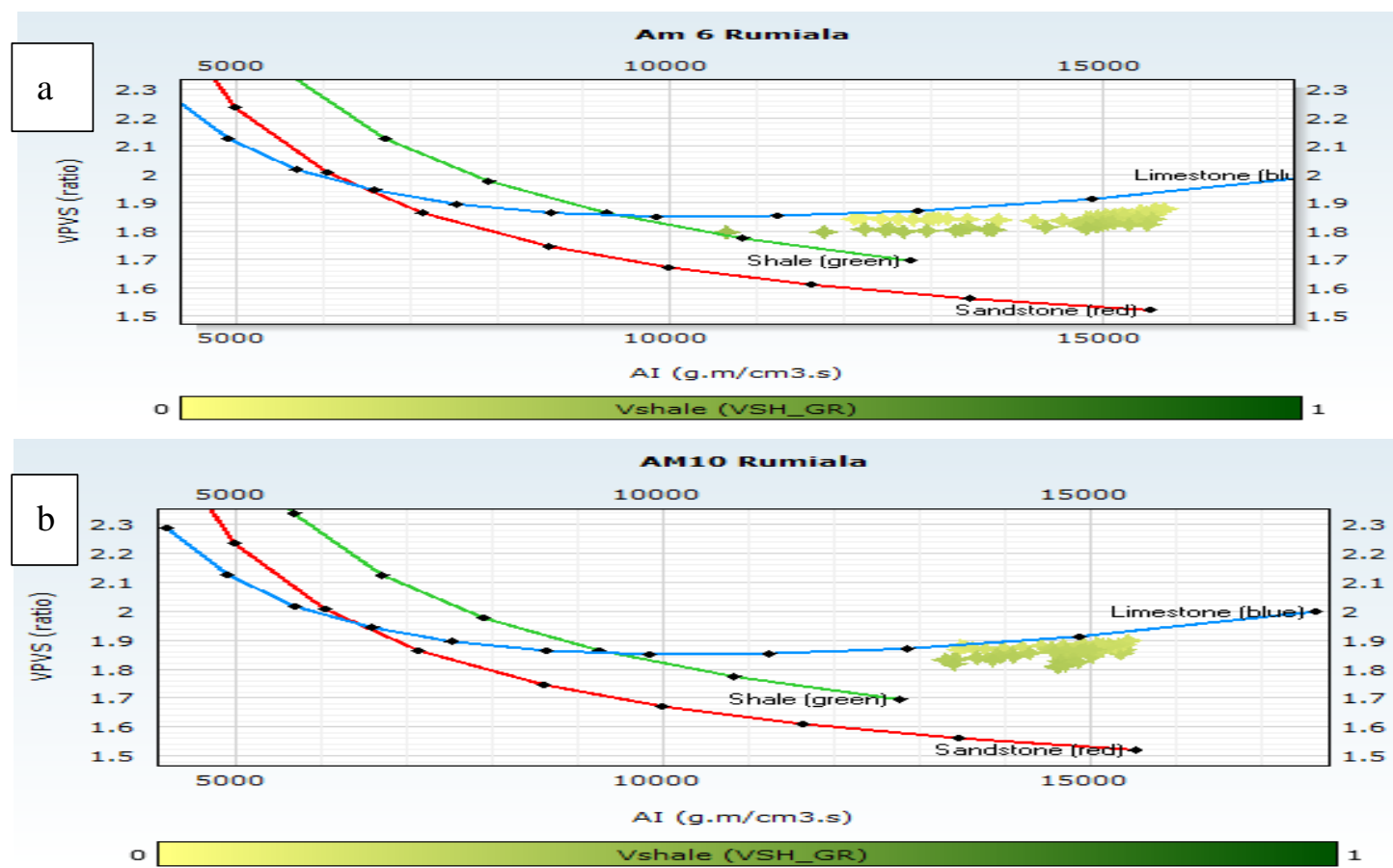

Fig. 12. The acoustic impedance versus the $\mathrm{Vp} / \mathrm{Vs}$ ratio colored by shale volume for the Rumaila Formation in Amara oil field a) at Am-6 b) at Am-10
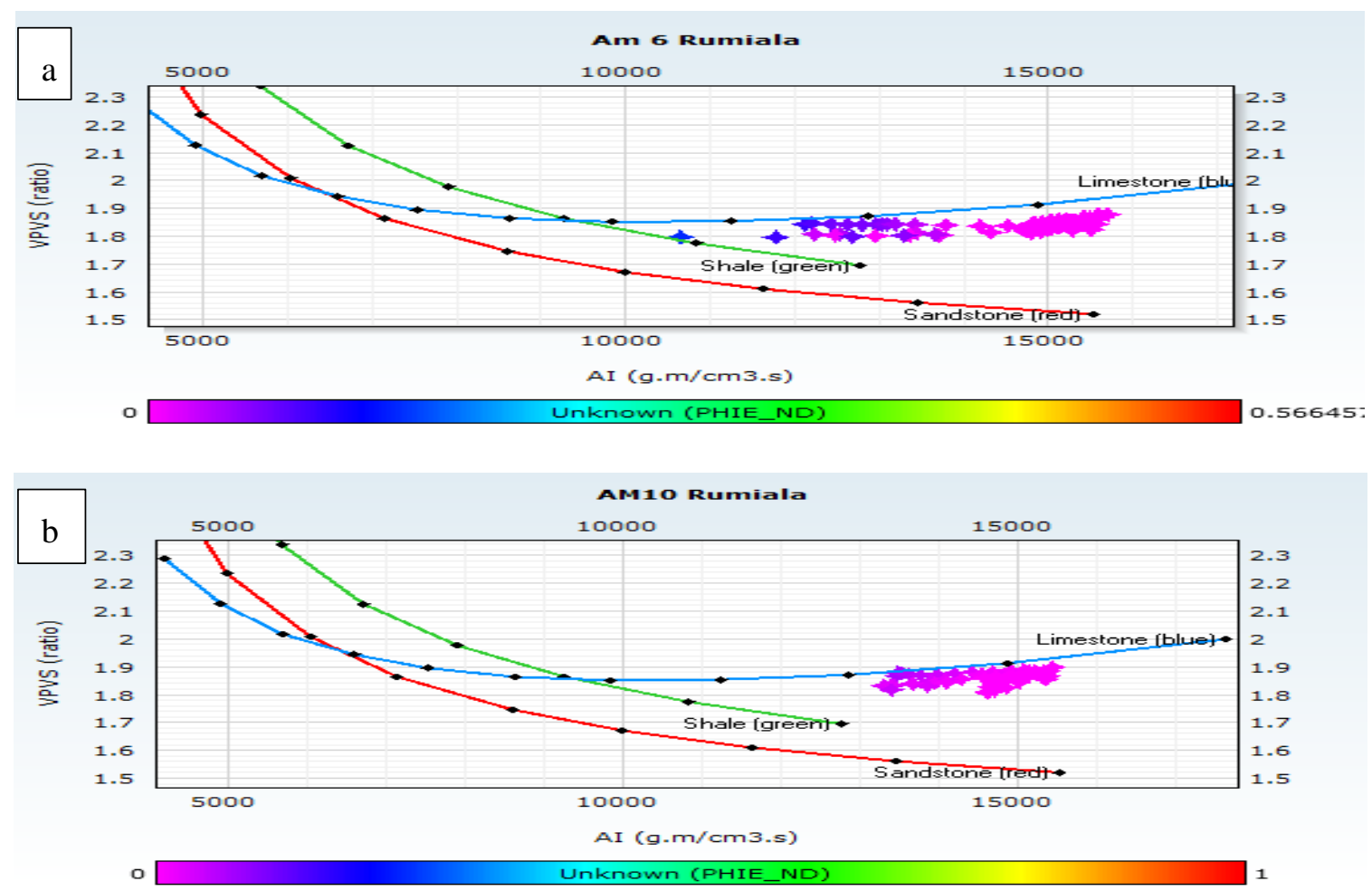

Fig. 13. the acoustic impedance versus the $\mathrm{Vp} / \mathrm{Vs}$ ratio colored by effective porosity for the Rumaila Formation in Amara oil field a) at Am-6 b) at Am-10 

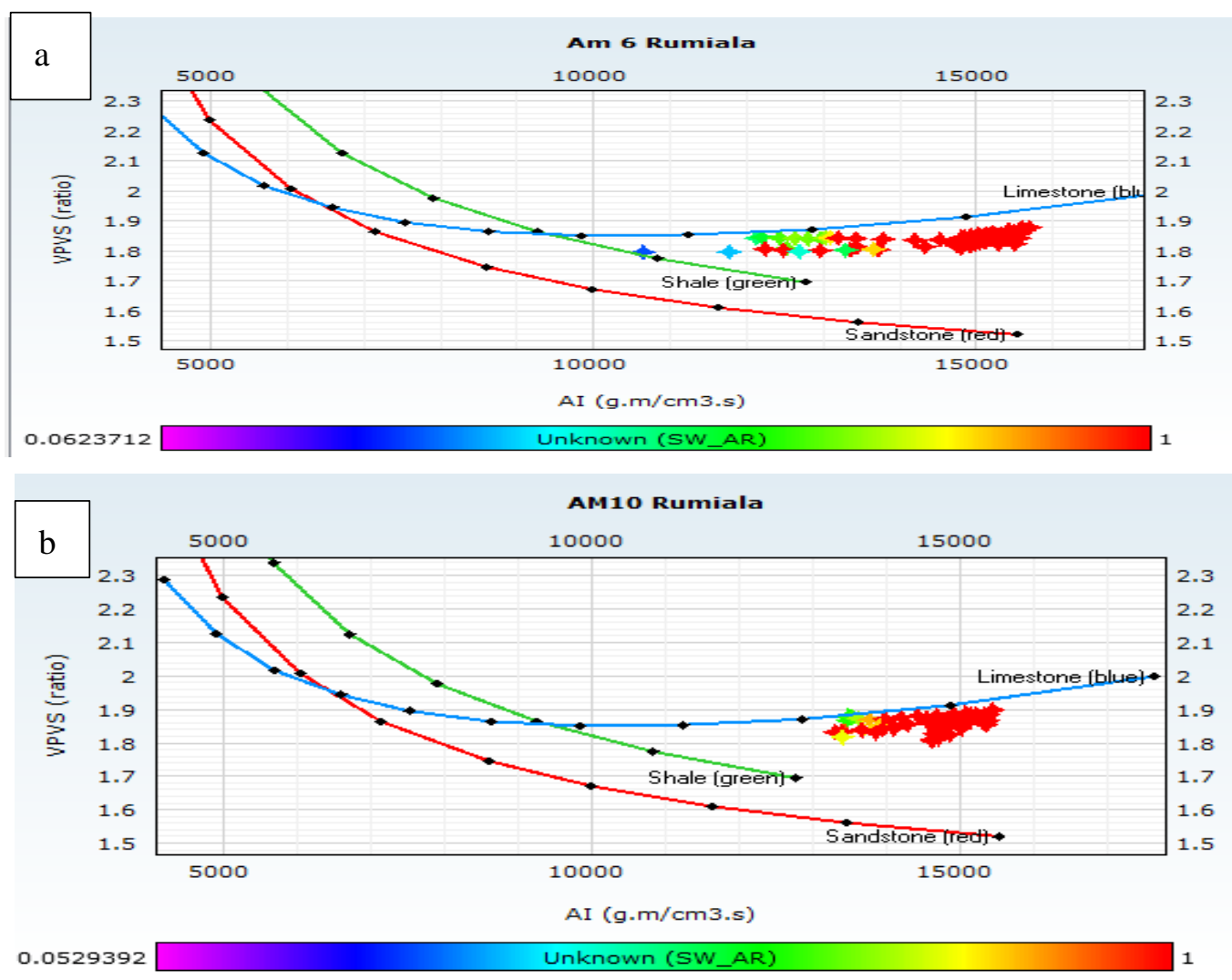

Fig. 14. The acoustic impedance versus the $\mathrm{Vp} / \mathrm{Vs}$ ratio colored by water saturation for the Rumaila Formation in Amara oil field a) at Am-6 b) at Am-10
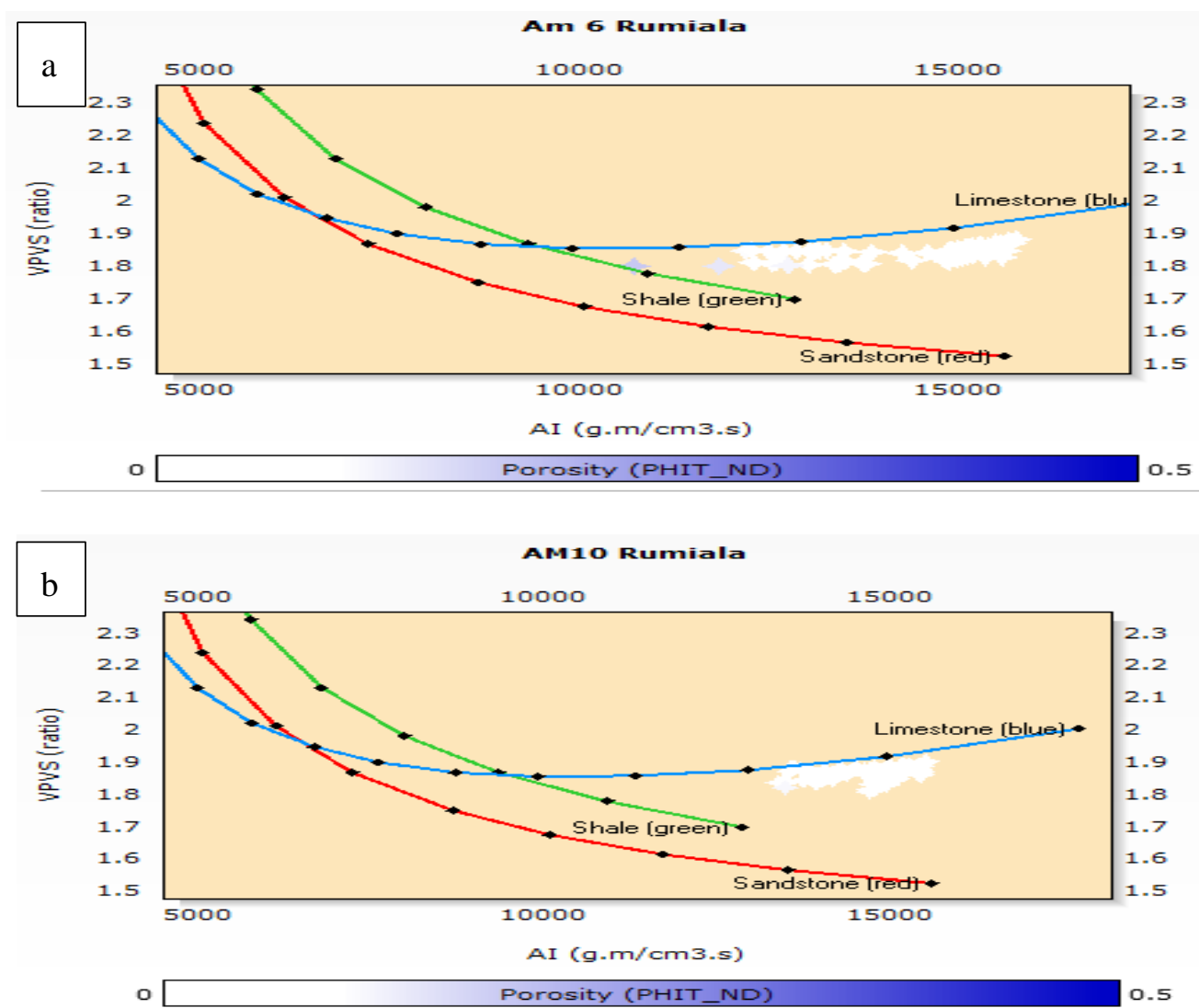

Fig. 15. The acoustic impedance versus the $\mathrm{Vp} / \mathrm{Vs}$ ratio colored by total porosity for Rumaila Formation in Amara oil field a) at Am-6 b) at Am-10 

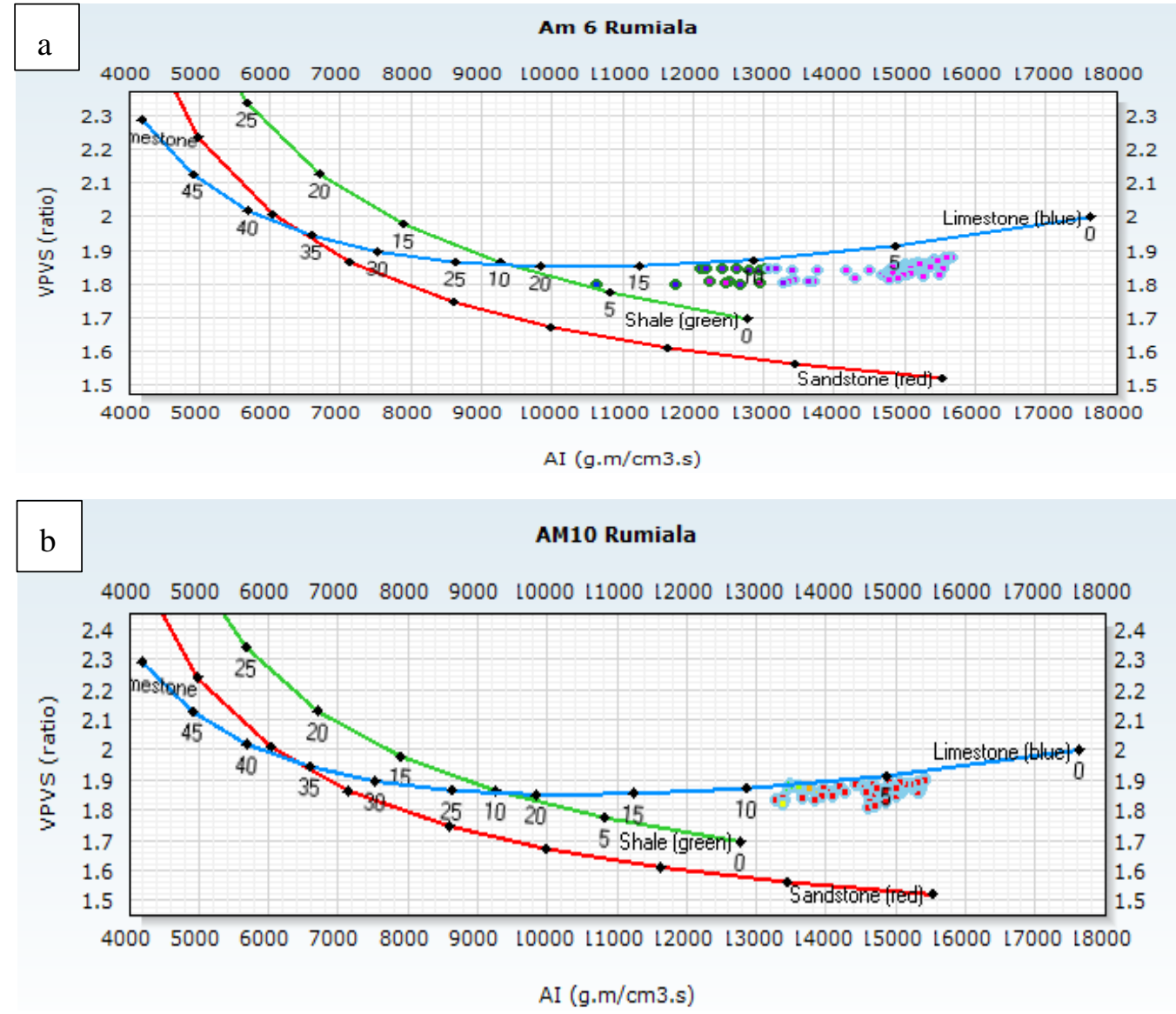

Fig. 16. Interpretation colored according to the value of the acoustic impedance versus the $\mathrm{Vp} / \mathrm{Vs}$ ratio for the Rumaila Formation in Amara oil field a) at Am-6 b) at Am-10

In Figs.17, 18, 19, 20 and 21, the points colored by blue have AI ranges between $11000-17100$ and $\mathrm{Vp} / \mathrm{Vs}$ ranges between 1.74 to 1.9 at Am- 6 and $\mathrm{AI}$ ranges between $11000-14800$ and $\mathrm{Vp} / \mathrm{Vs}$ ranges between 1.73-1.9 at Am-10 and it represent the low porosity, low Vsh and high-water saturation representing low porosity limestone depths with water fluid. The green points reflect higher Vsh, EPHI, and TPHI and lower $\mathrm{Sw}$ than blue area, the AI ranges between 6100 - 13000 and $\mathrm{Vp} / \mathrm{Vs}$ ranges between 1.71 to 2.17 at Am-6 and AI ranges between $7537-13000$ and $\mathrm{Vp} / \mathrm{Vs}$ ranges between 1.73-1.97 at Am10. It represents pores limestone with high shale volume and water saturation fluid. Figs. 22, 23, 24, 25 and 26 show the Mauddud formation distribution points in the AI \& Vp/Vs cross plot, the formation points are classified to blue area points which reflect $\mathrm{AI}$ range between $14000-17100$ and $\mathrm{Vp} / \mathrm{Vs}$ range between 1.72 to 1.94 at Am-6 and AI range between 13000 - 16300 and $\mathrm{Vp} / \mathrm{Vs}$ range between 1.781.97 at Am-10 and it represent the low porosity, low Vsh and low Vsh, TPHI, EPHI and high Sw that means low porosity limestone with water fluid type.

The green points reflect higher EPHI, and TPHI and lower Sw than blue area, the AI ranges between $10000-13000$ and $\mathrm{Vp} / \mathrm{Vs}$ ranges between 1.8 to 1.9 at Am-6 and $\mathrm{AI}$ ranges between $10000-13000$ and $\mathrm{Vp} / \mathrm{Vs}$ ranges between 1.78-1.94 at Am-10. It represents pores limestone with high shale volume and water saturation fluid. The light green points have lower acoustic impedance and range of $\mathrm{Vp} / \mathrm{Vs}$ from low to high, this area reflects points with high porosity and low $\mathrm{Sw}$, the points with low AI and low $\mathrm{Vp} / \mathrm{Vs}$ indicates oil fluid found in pores. 

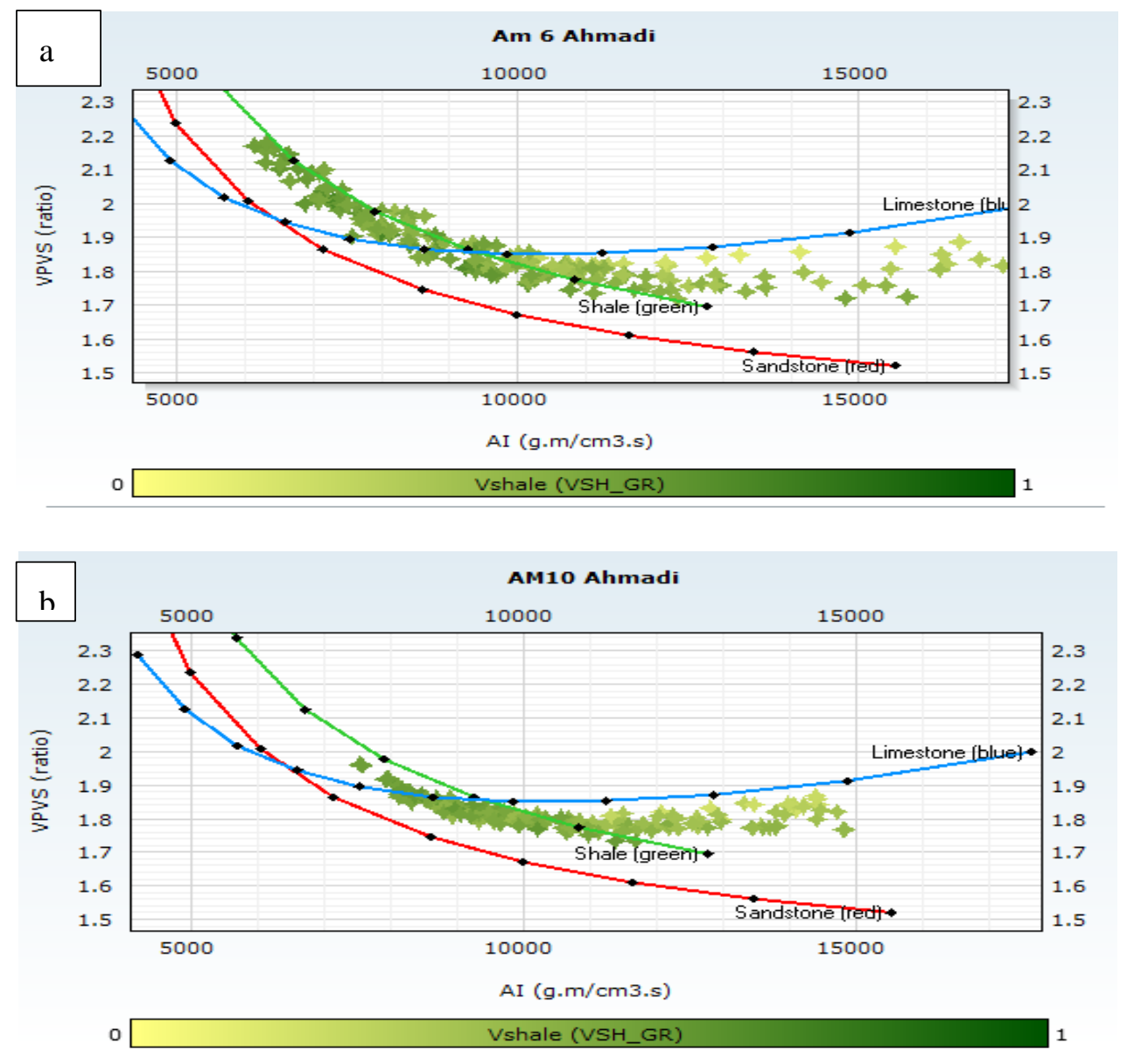

Fig. 17. The acoustic impedance versus the $\mathrm{Vp} / \mathrm{Vs}$ ratio colored by shale volume for the Ahmadi Formation in Amara oil field a) at Am-6 b) at Am-10
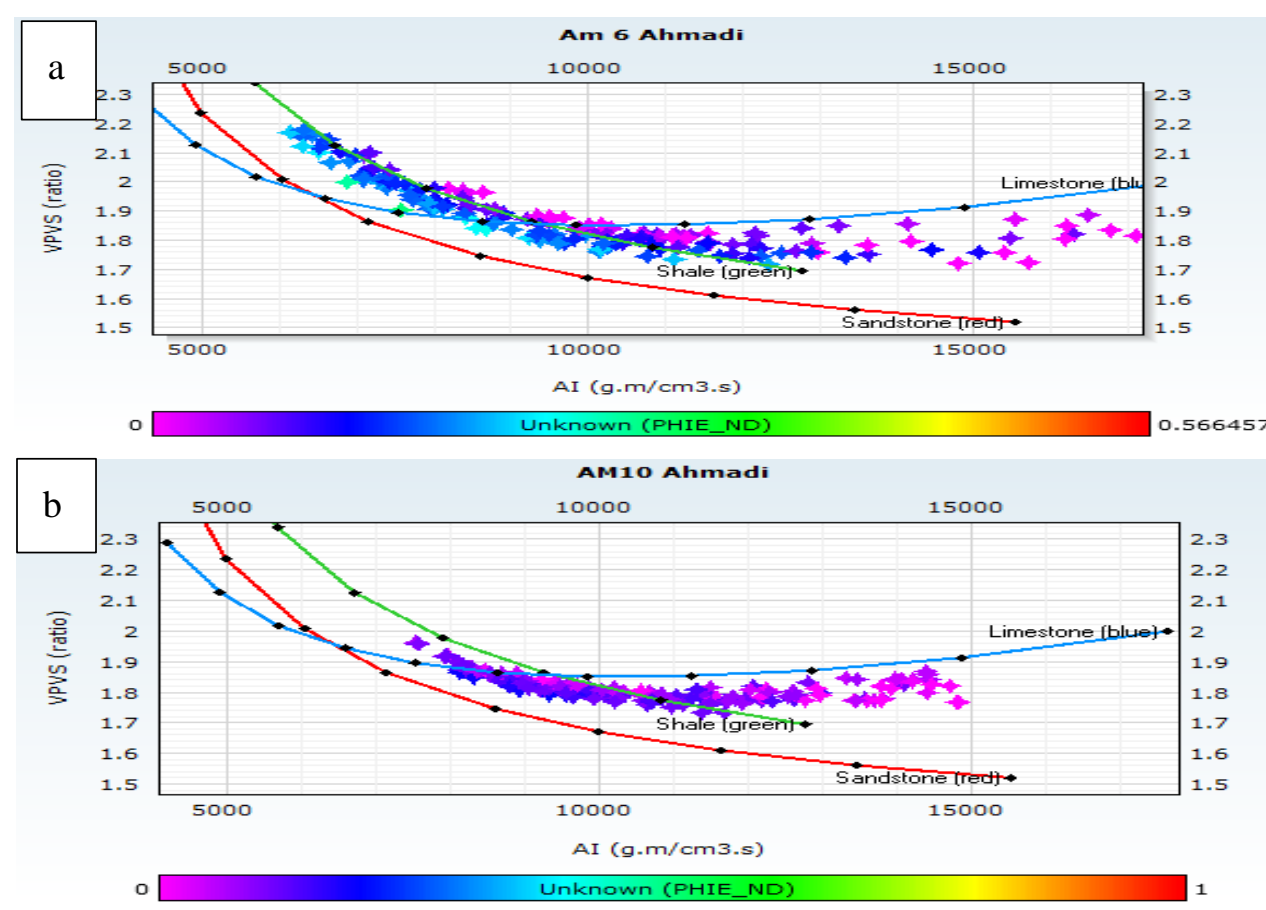

Fig. 18. The acoustic impedance versus the Vp/Vs ratio colored by effective porosity for the Ahmadi Formation in Amara oil field a) at Am-6 b) at Am-10 

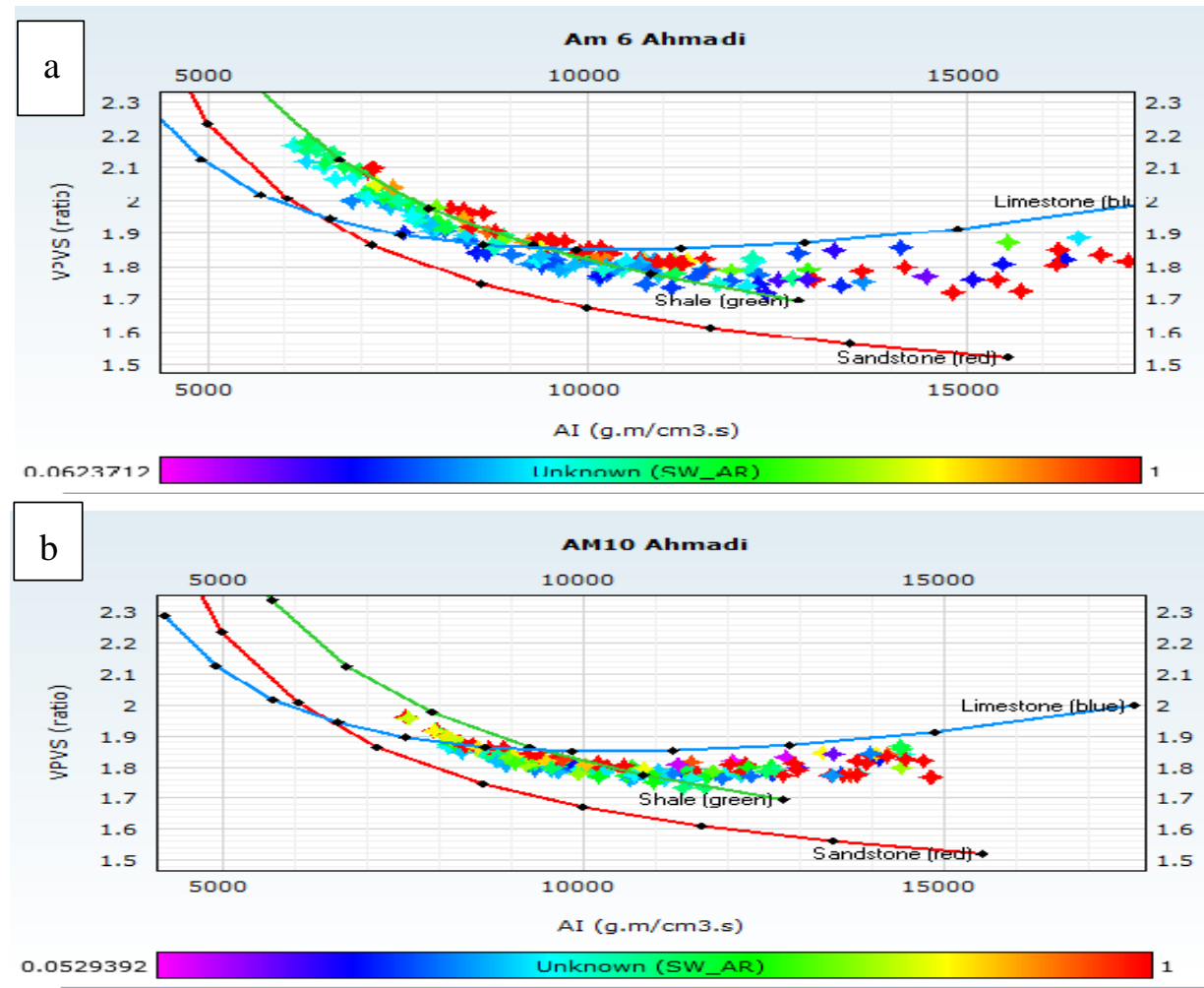

Fig. 19. The acoustic impedance versus the $\mathrm{Vp} / \mathrm{Vs}$ ratio colored by water saturation for the Ahmadi Formation in Amara oil field a) at Am-6 b) at Am-10
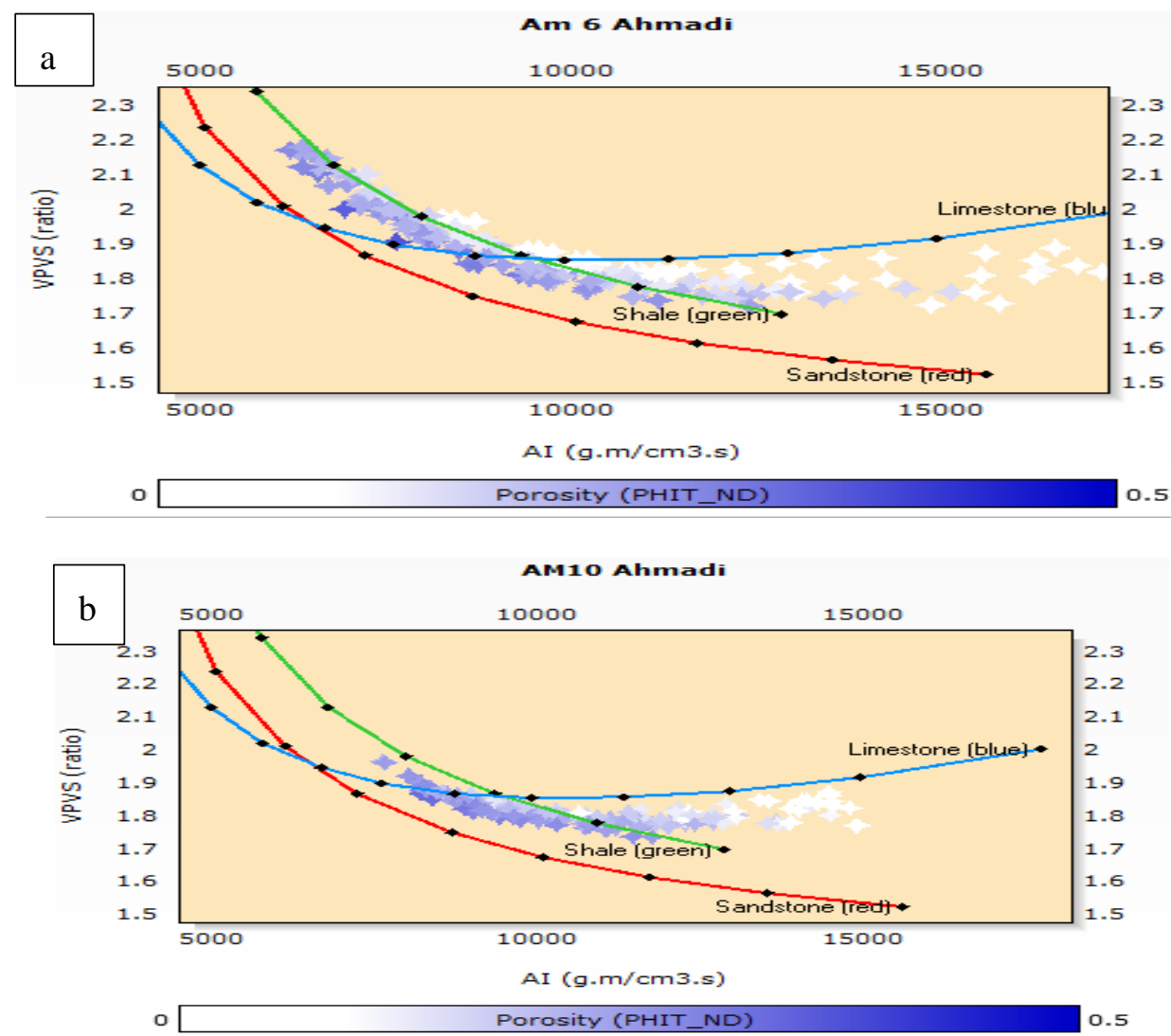

Fig. 20. The acoustic impedance versus the $\mathrm{Vp} / \mathrm{Vs}$ ratio colored by total porosity for Ahmadi Formation in Amara oil field a) at Am-6 b) at Am-10 

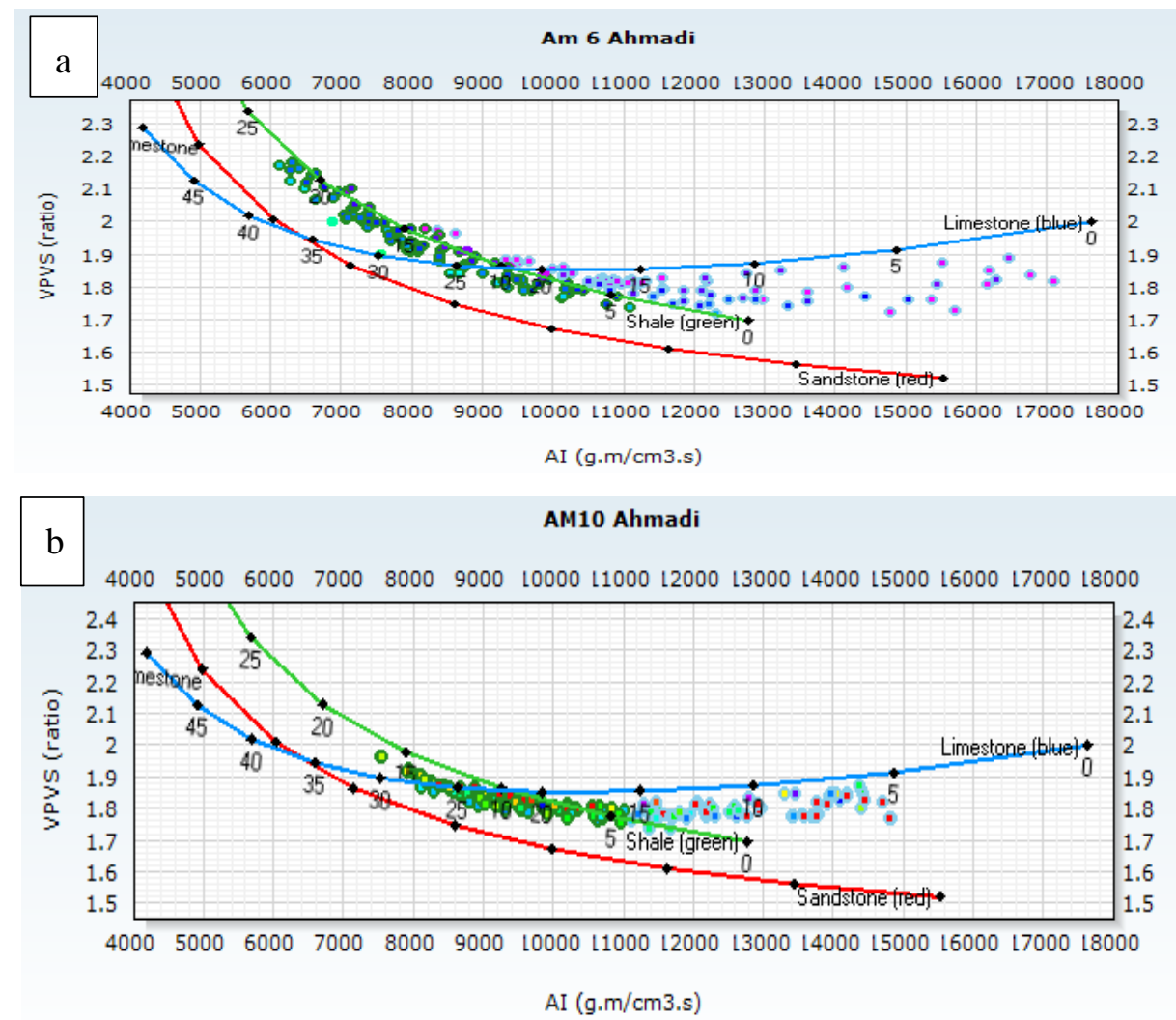

Fig. 21. Interpretation colored according to the value of The Acoustic Impedance versus the Vp/Vs ratio for the Ahmadi Formation in Amara oil field a) at Am-6 b) at Am-10
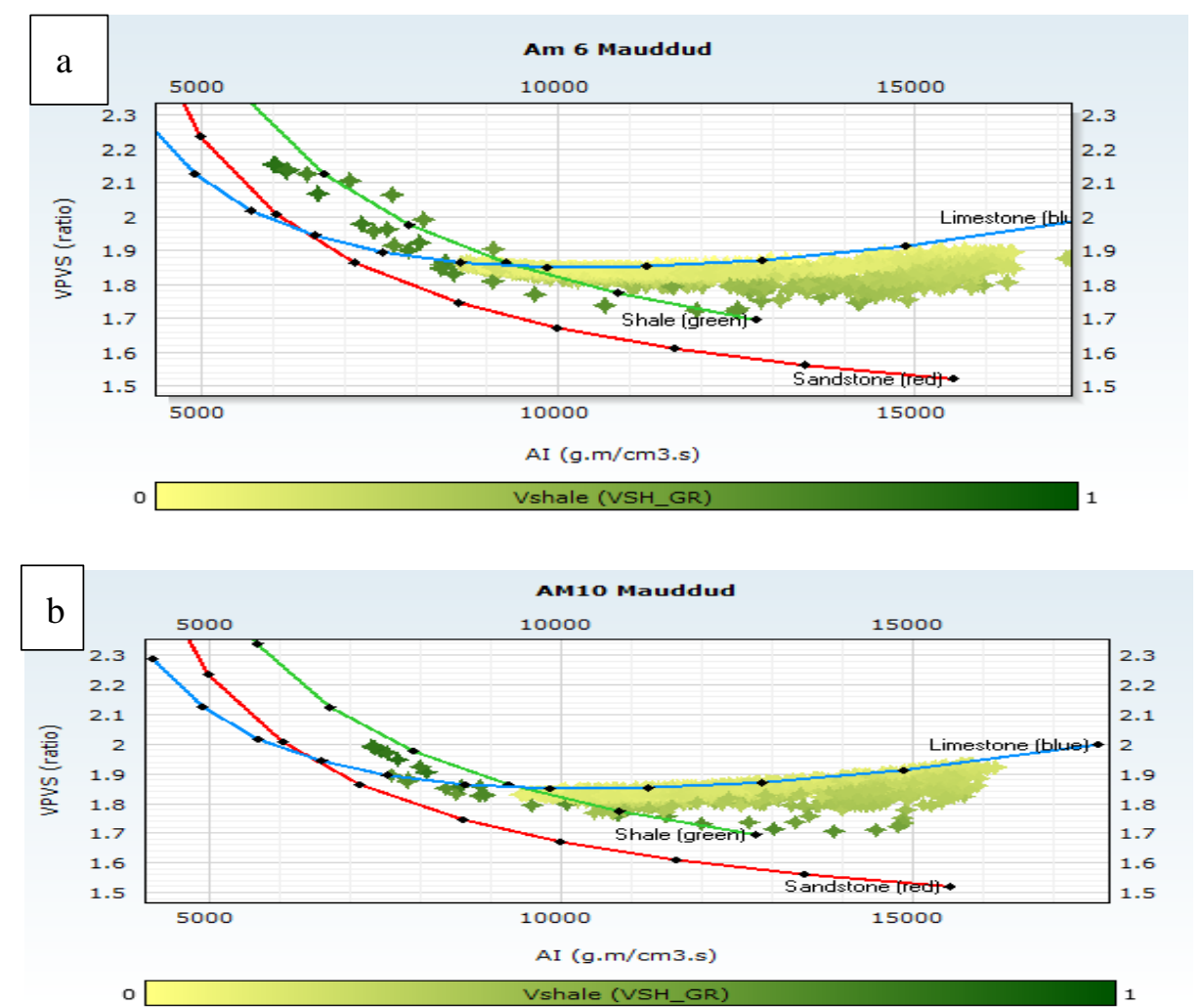

Fig. 22. The acoustic impedance versus the $\mathrm{Vp} / \mathrm{Vs}$ ratio colored by shale volume for the Mauddud Formation in Amara oil field a) at Am-6 b) at Am-10 

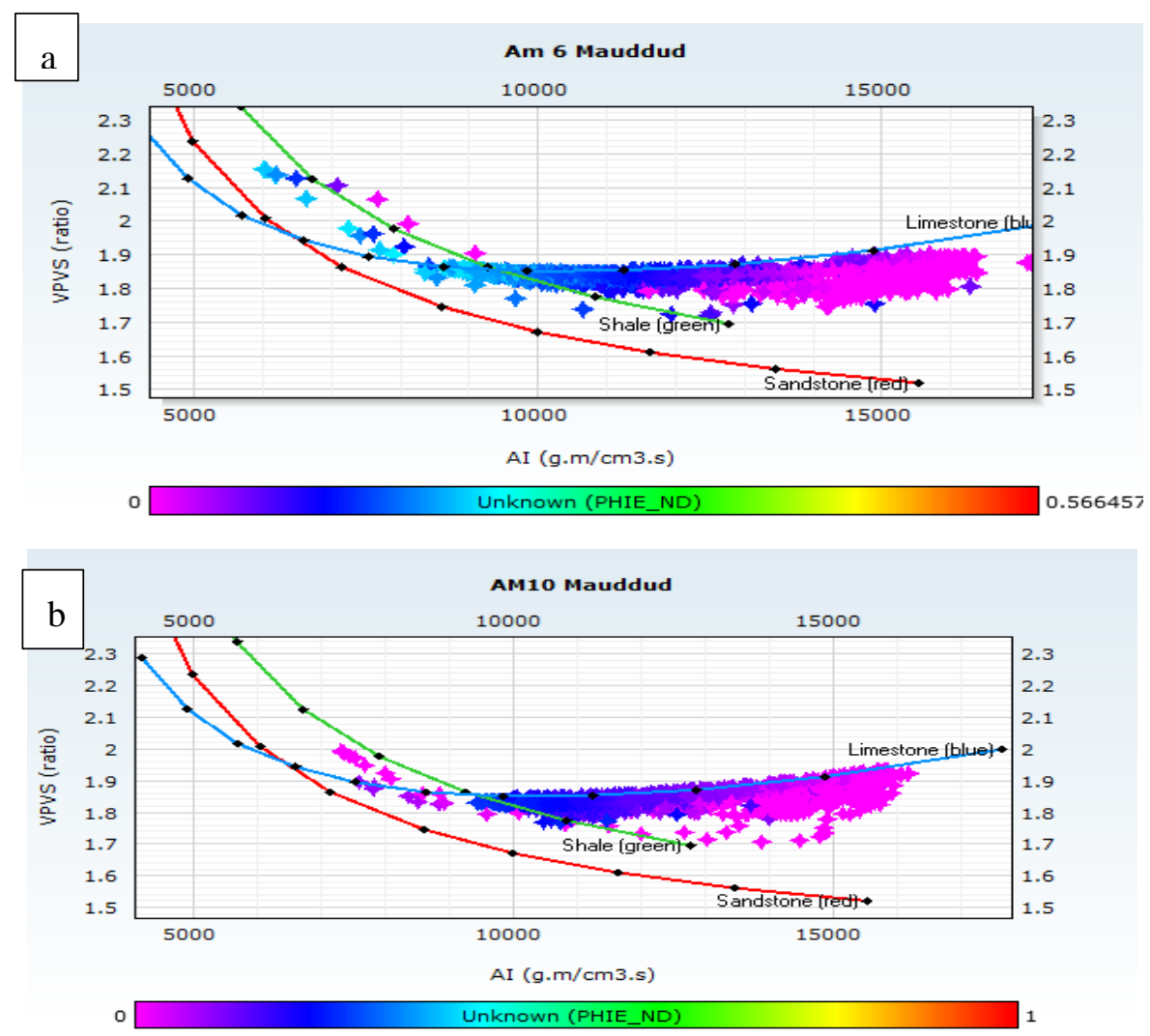

Fig. 23. The acoustic impedance versus the $\mathrm{Vp} / \mathrm{Vs}$ ratio colored by effective porosity for the Mauddud Formation in Amara oil field a) at Am-6 b) at Am-10
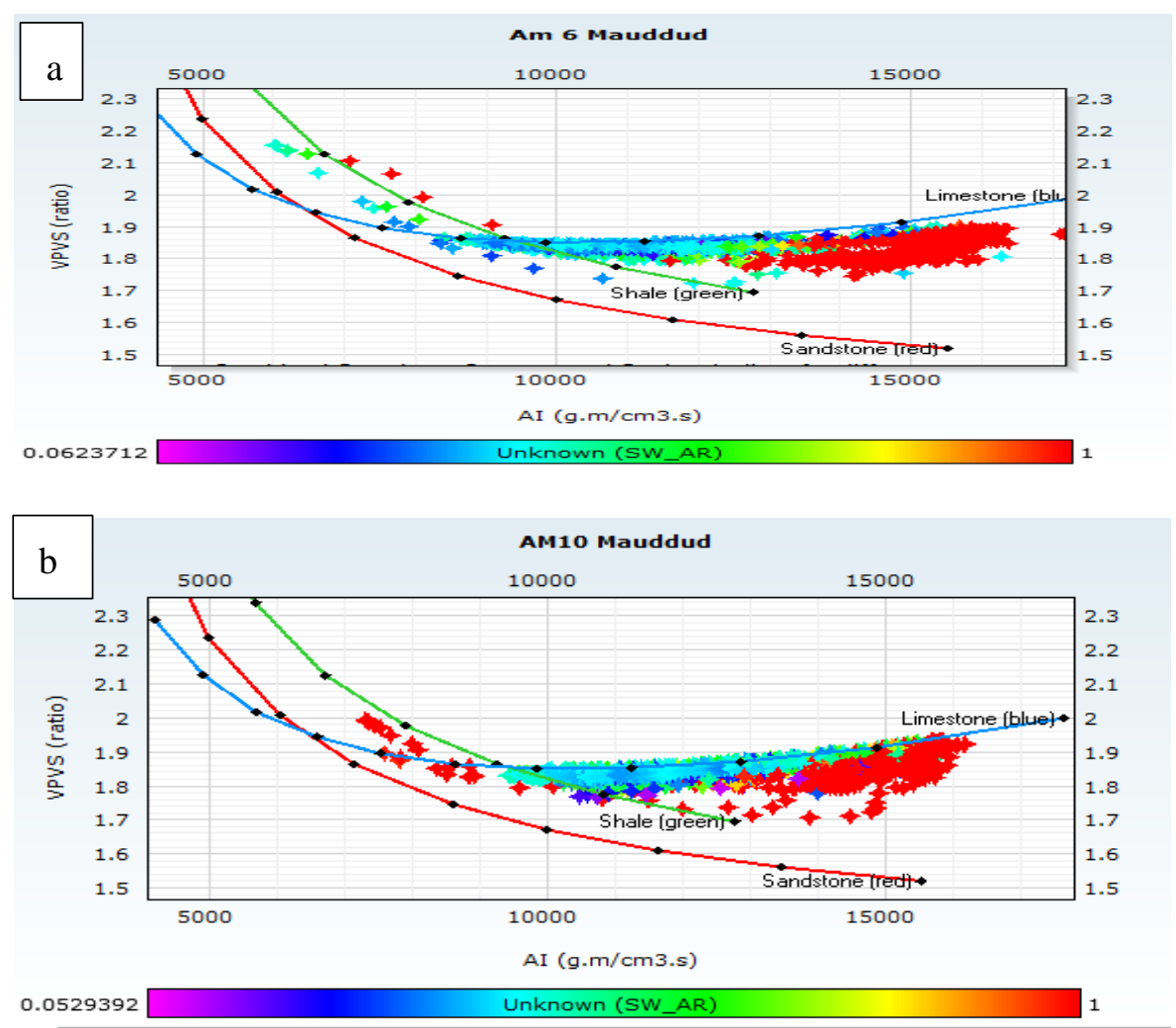

Fig. 24. The acoustic impedance versus the Vp/Vs ratio colored by water saturation for the Mauddud Formation in Amara oil field a) at Am-6 b) at Am-10 

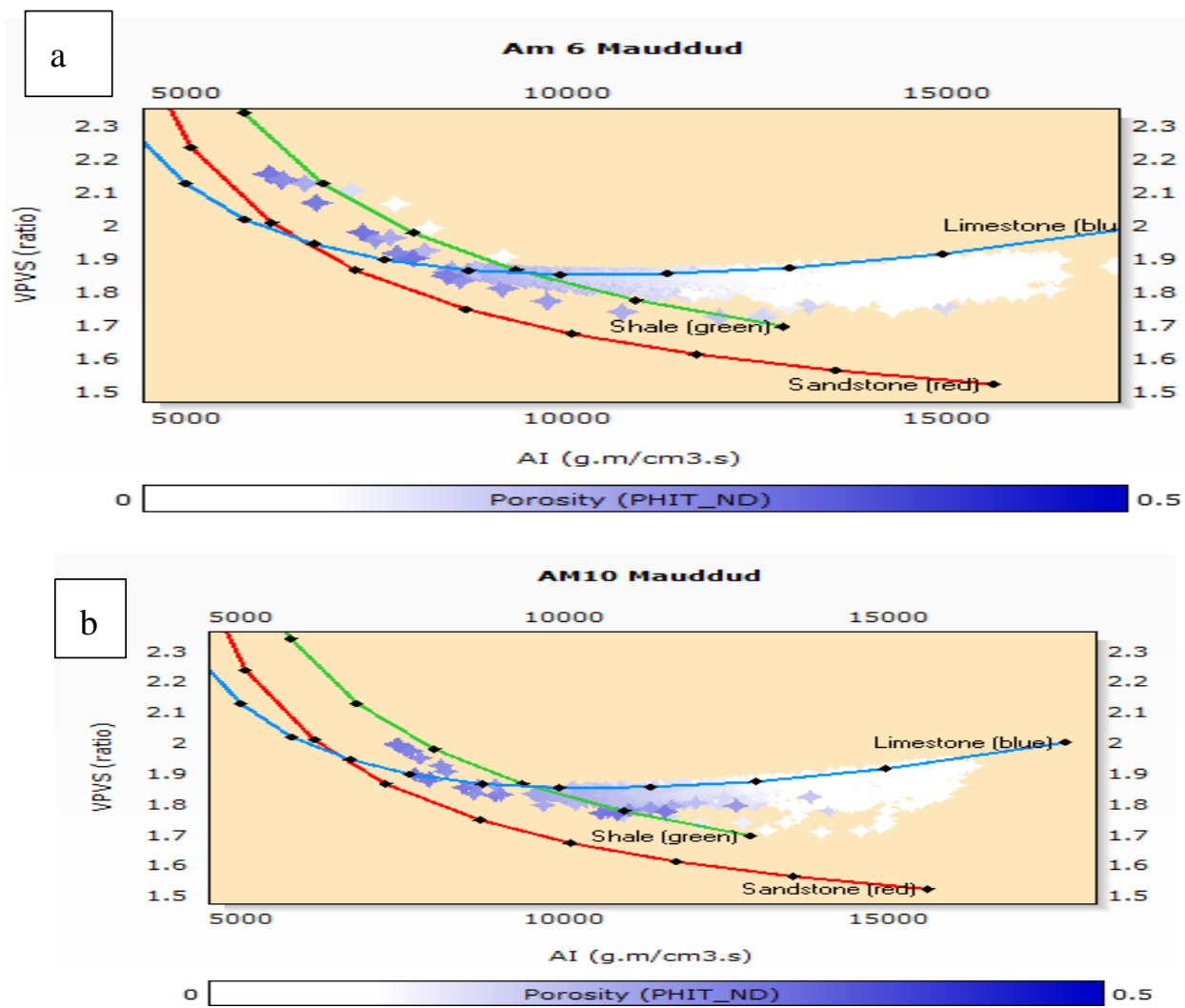

Fig. 25. The acoustic impedance versus the $\mathrm{Vp} / \mathrm{Vs}$ ratio colored by total porosity for the Mauddud Formation in Amara oil field a) at Am-6 b) at Am-10
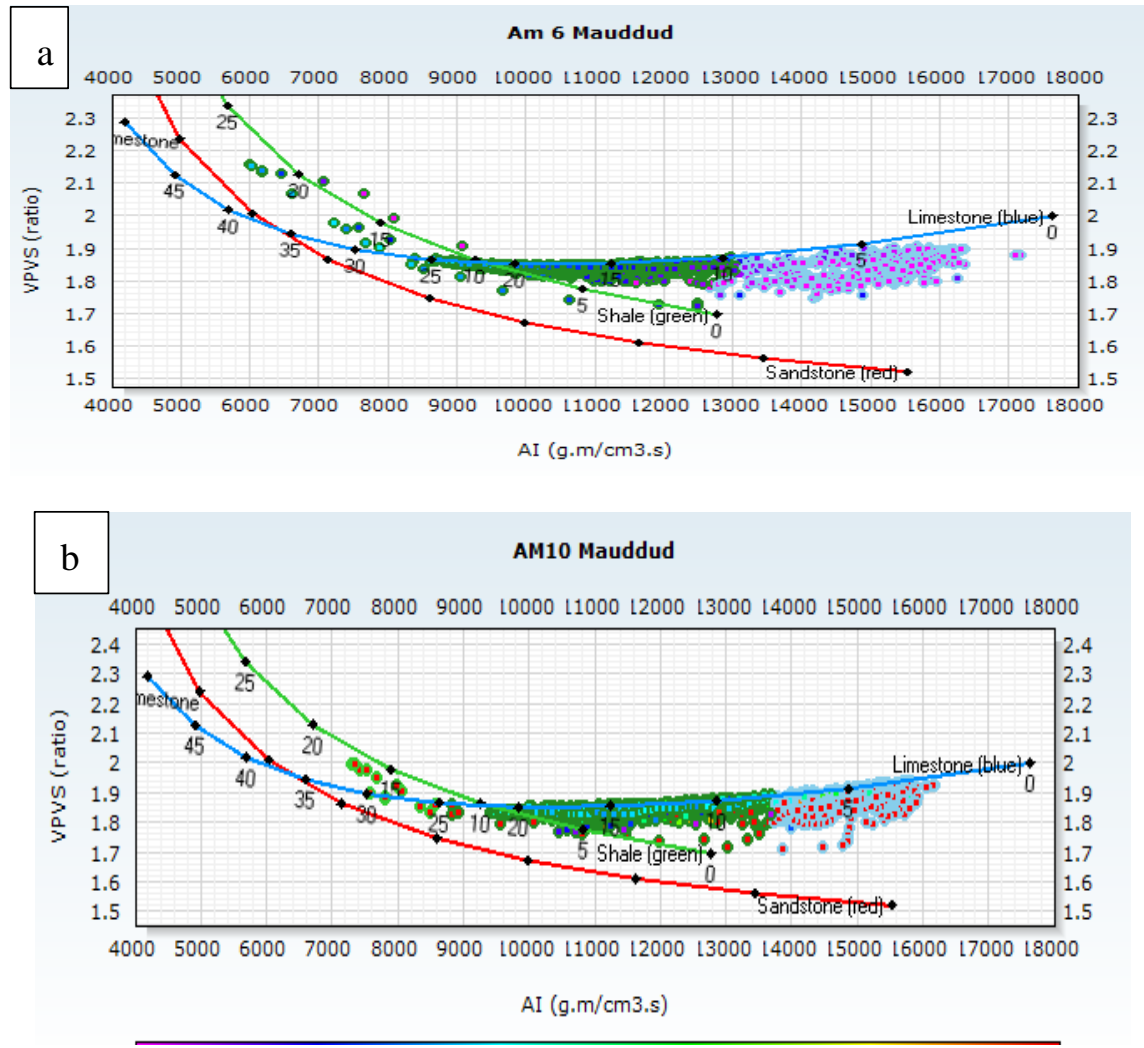

Fig. 26. Interpretation colored according to the value of the acoustic impedance versus the Vp/Vs ratio for the Mauddud Formation in Amara oil field a) at Am-6 b) at Am-10 


\section{The Final Interpretation of $\log$}

In Figs. 27 and 28 the corrected for hole size bulk density, the velocity ratio, compressional and shear velocities, Acoustic impedance fluid density, total, effective porosity and shale volume (this Vsh $\log$ calculated using GR $\log$ ) logs were drawn as a final interpretation image. These images colored with depth (green and blue) according to the interpretation-colored zones that have been discussed above for each formation. The low-density depths with low velocity and AI with green color represent high porosity limestone with high Vsh low densities rocks and range of Sw. The blue depths represent high bulk density and low porosity high AI, Vp, Vs and high water saturation in this low porosity and it indicates low porosity limestone. From these final images we notice that Mishrif Formation contain of almost nine zones of high porosity total and effective separated by six hard zones represented in blue area with high water saturation, Rumiala Formation have low thickness consist of only hard limestone with very low porosity and high-water saturation. Ahmadi Formation has high shale volume limestone with high total porosity low effective porosity and high-water saturation. Mauddud Formation has two main zones of pores limestone with range of water saturation represented by green color and separated by hard limestone layers with high water saturation in blue color.

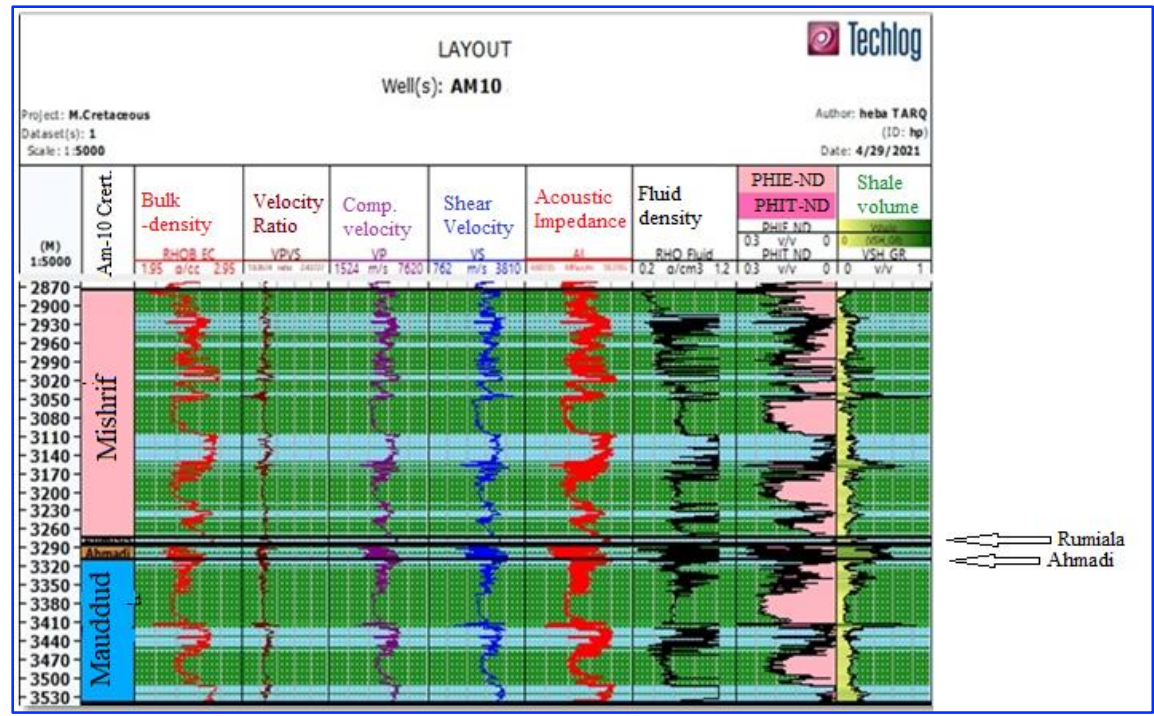

Fig. 27. The interpretation logs of Am-10 well in Amara oil field, Southern Iraq

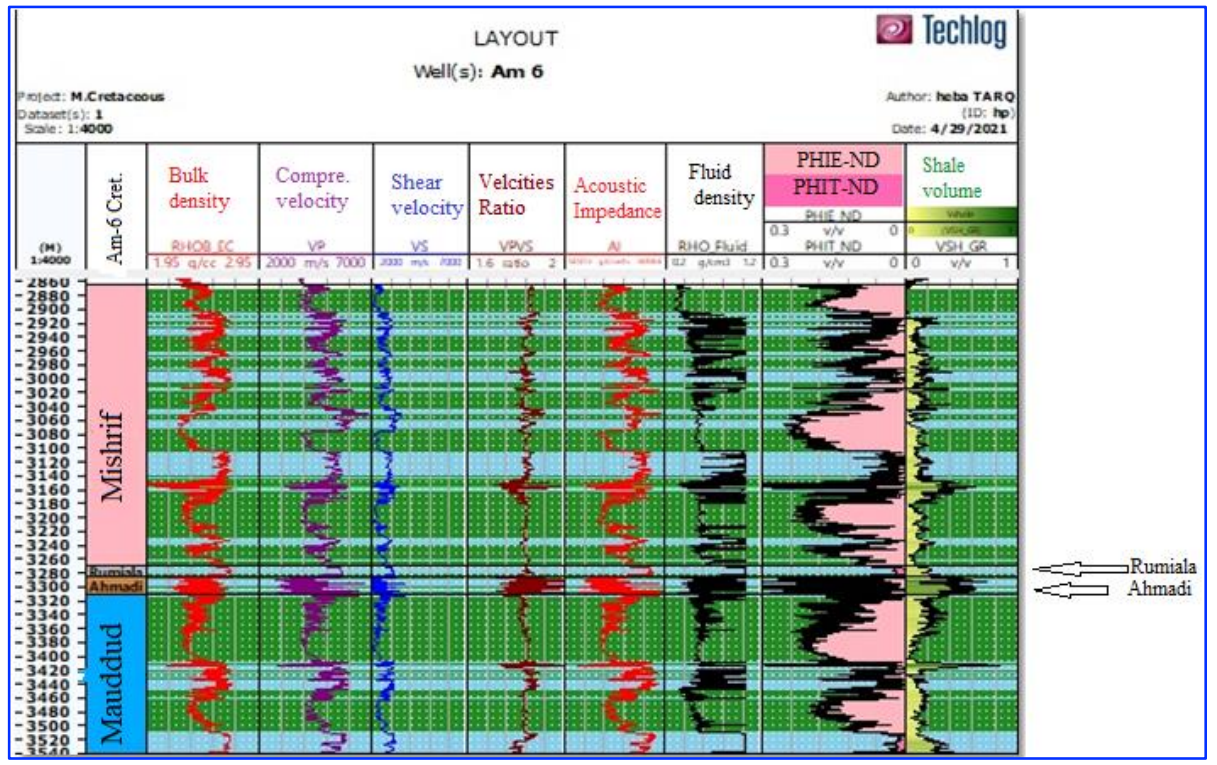

Fig. 28. The interpretation logs of Am-6 well in Amara oil field, Southern Iraq 


\section{Conclusions}

The use of rock physics crossplot between $\mathrm{AI}$ and $\mathrm{Vp} / \mathrm{Vs}$ ratio to evaluate lithology, fluid type at Amara oil field. The data were taken from two wells Am-6 and Am-10. The results show that Mishrif, Rumaila, Ahmady and Mauddud formations are mainly composed of limestone (high porosity limestone separated by low porosity limestone). The Mishrif Formation contains of almost nine zones of high porosity total and effective separated by six hard zones represented in blue area with high water saturation, the Rumaila Formation have low thickness consist of only hard limestone with very low porosity and high-water saturation. The Ahmadi Formation has high shale volume limestone with high total porosity low effective porosity and high-water saturation. The Mauddud Formation has two main zones of pores limestone with range of water saturation represented by green color and separated by hard limestone layers with high water saturation in blue color, this formation end by non-pores limestone layer. The zone with high $\mathrm{Vp} / \mathrm{Vs}$ and high $\mathrm{AI}$ indicates water fluid within low porosity rocks and that exists in all formation represented in blue color. The low amount of both $\mathrm{AI}$ and $\mathrm{Vp} / \mathrm{Vs}$ ratio indicates zone of hydrocarbon fluid and that exists in Mishrif and Mauddud formations represented in green colored.

\section{Acknowledgements}

The authors are very grateful to Missan Oil Company, Ministry of Oil for providing the well log data and reports that is necessary to complete this study. Thanks also to the Editor in Chief Prof. Dr. Salih M. Awadh, the Secretary of Journal Mr. Samir R. Hijab. and the Technical Editors for their great efforts and valuable comments

\section{References}

Al-Baldawi, B. A., 2020. Determination of pore types and porosity trends using of velocity deviation log for the carbonate Mishrif reservoir in Halfaya oil field, Southeast Iraq. Iraqi Geological Journal.53 (1D), 26-37.

AL-Baldawi, B. A., 2015. Applying the cluster analysis technique in log facies determination for Mishrif Formation, Amara oil field, South Eastern Iraq. Arabian Journal of Geosciences. 8 (6), 3767-3776.

Al-Banna, A. S., Ali, K. K., 2018. The transition tectonic zone between the two parts of the platform in Iraq: A Review Study. Iraqi Journal of Science. 59 (2C), 1086-1092.

Al-Mimar, H.S., Awadh, S.M., Al-Yaseri, A.A. and Yaseen, Z.M., 2018. Sedimentary units-layering system and depositional model of the carbonate Mishrif reservoir in Rumaila oilfield, Southern Iraq. Modeling Earth Systems and Environment, 4(4),1449-1465.

Aqrawi, A., Horbury, A. D., Goff, J., Sadooni, F., 2010. The Petroleum Geology of Iraq. 424pp.

Asquith, G. B., Krygowski, D., 2004, Basic Well Log Analysis, 2nd Edition, 244pp.

Avseth, P., Wijngaarden, A.J., Mavko, G., Johansen, T.A., 2006. Combined porosity, saturation and net-to-gross estimation from rock physics templates: 76th Annual Meeting, SEG Expanded Abstracts, 1856-1860.

Awadh, S. M., Al-Mimar, H.S. and Al-Yaseri, A.A., 2018. Salinity mapping model and brine chemistry of Mishrif reservoir in Basrah oilfields, Southern Iraq. Arabian Journal of Geosciences, 11(18), 1-12.

Colin, C., Potter., Darren Foltinek, S., 1997. Formation elastic parameters by deriving S-wave velocity logs CREWES Research, 9, 1-10.

Fouad, S. F., 2010. Tectonic and structural evaluation of the Mesopotamian fore deep, Iraq. Iraqi Bulletin of Geology and Mining. 6 (2), 41-53.

Greenberg, M. L., Castagna, J. P., 1992. Shear-wave velocity estimation in porous rocks: theoretical formulation, preliminary verification and applications. Geophysical Prospecting, 40 (2), 195-209.

Hami-Eddine, K., Klein, P., Loic, R., Ribet, B., Grout, M., 2015. A new technique for lithology and fluid content prediction from pre-stack data: An application to carbonate reservoir. Interpretation, 3(1), 19-32.

IPEC., 2010. Amara Oil Field Assessment. Maysan Oil Company, Department of Geology, 30.

Khanawi, M.A., Abdu-Alahad, R.J., Sari, J.R., Abdu-Asaheb, H., Mohamed, A.H., Jaafer, K.H., Salman, S.J., 2010. Geological evaluation study for Amara field, Iraqi Oil Explorations Company. 
Latimer, R.B., Davison, R., Van Riel, P., 2000. An interpreter's guide to understanding and working with seismicderived acoustic impedance data", Lead. Edge, 19, 242-256.

Messan Oil Company (MOC), 2011. Reservoir and Fields Development, Geology Department., Ministry of Oil, Baghdad, Iraq.

Messan Oil Company (MOC), 2011. Final geological report for Am6. Geology Department., Ministry of Oil, Messan, Iraq.

Messan Oil Company (MOC), 2015. Final geological report for Am10. Ministry of Oil, Messan, Iraq.

Mohammed, A. K., 2018. Reservoir characteristics of Khasib Formation in Amara field, southern Iraq .Iraqi Geological Journal. 51(2A) 54-74.

Mohammed, A. K., Radhi, J. K., Ali, S. Z., 2020. Well logs data prediction of the Nahr Umr and Mishrif formations in the Well Noor-10, Southern Iraq. Iraqi Geological Journal.53 (2A), 50-67.

Nassir, N. A., Al-Banna, A. S., Al-Sharaa, G. H., 2020. The using of Vp/Vs Ratio and P- for differentiate both fluid sand lithology depending on rock physics templates model of Mishrif and Nahr Umr Formations in Kumait and Dujaila oil fields Sothern Iraq. Bulletin of Pure and Applied Sciences. 39F (2), 285-300.

Sadooni, F.N., 2004. Stratigraphy depositional setting and reservoir characteristics of Turonian- Campanian carbonates in central Iraq. Journal of Petroleum Geology. 27(4), 357-371.

Wang, P., Peng, S., 2019. On a new method of estimating shear wave velocity from conventional well logs. Journal of Petroleum Science and Engineering. 180, 105-123. 